\title{
The Economic Effects of Earnings Management Pre- and Post-SOX
}

Terry W. Mason*

Richard M. Morton ${ }^{* *}$

\author{
Kansas State University \\ 2139 Business Building \\ 1301 Lovers Ln \\ Manhatan, KS 66506 \\ Email: twmason@ksu.edu \\ ** $\quad$ Florida State University \\ 821 Academic Way \\ Tallahassee, FL 32304 \\ Email: rmorton@business.fsu.edu
}

JEL Classifications: G32, G38, M41, M48

Keywords: Sarbanes-Oxley, Real Activities Manipulation, Accrual Earnings Management, Earnings Management

Data Availability: Data are publicly available from sources identified in the paper.

Current Version as of October 1, 2017.

We appreciate the comments of Allen Bathke, Allison Beck, Bruce Billings, Dave Bryan, Dan Deines, Jeremy Douthit, Bud Fennema, Amy Hageman, Frank Heflin, Christina Lewellen, Landon Mauler, Robbie Moon, John Morris, Kingsley Olibe, Jeffrey Patterson, Spencer Pierce, Kenny Reynolds, Zabihollah Rezaee, Joseph Ugrin, Kenton Walker, Brett Wilkinson, Joseph Zhang, Tim Zhang, Tom Zuehlke (Economics) and workshop participants at Florida State University, Kansas State University, and the University of Memphis. We also appreciate the comments of participants at the American Accounting Association Annual Meetings and Jimmy Lee, the discussant, for his thoughtful comments and suggestions. 


\title{
The Economic Effects of Earnings Management Pre- and Post-SOX
}

\begin{abstract}
While prior research suggests that firms have primarily switched from accrual to real earnings management strategies since the passage of the Sarbanes-Oxley Act of 2002 (SOX) (Cohen, Dey, and Lys 2008), there has been limited research on the effects that this switch might have on future performance and firm value. Accrual earnings management shifts income recognition without directly affecting cash flows, whereas real earnings management implies suboptimal decisions that directly affect the underlying cash flows. Thus, this shift in earnings management techniques could have important consequences for investors. Consistent with increased real earnings management post-SOX, we find that abnormal operating decisions are less informative about future return on assets (ROA) and have a more negative effect on firm value relative to the pre-SOX period. Alternatively, consistent with less accrual earnings management post-SOX, we find that discretionary accruals are more informative about future ROA and there is less evidence of market mispricing relative to the pre-SOX period. Finally, we examine the net effect that SOX has had on earnings management and find that the lower future returns and firm performance associated with greater real earnings management outweigh the positive effects of improved accrual quality.
\end{abstract}




\section{The Economic Effects of Earnings Management Pre- and Post-SOX}

\section{Introduction}

A major objective of the Sarbanes-Oxley Act of 2002 (SOX) was to restore investor confidence in the financial reporting process by curbing accounting manipulation. While research finds that income-increasing discretionary accrual activity declined after the passage of SOX, several studies suggest that efforts to boost earnings by altering "real" activities increased after SOX (Cohen, Dey, and Lys 2008, Bartov and Cohen 2009). However, these two forms of earnings management have very different implications for future firm performance. Whereas accrual earnings management (AEM) shifts income across periods with no direct effect on cash flows, real earnings management (REM) involves operating decisions that alter cash flows in a way that presumably sacrifices long-run value (Graham, Harvey and Rajgopal 2005). Given the apparent shift in earnings management strategies, we consider the economic consequences of REM and AEM before and after SOX. Specifically, are managers more willing to sacrifice firm value for short-term gain, and how does the market perceive this change in discretionary activity? Our study addresses these issues by investigating how the long-term implications and investor pricing of real activities management and discretionary accruals change after the passage of SOX. ${ }^{1}$

An extensive body of research suggests that some managers acting in their own selfinterest affect reported earnings to mislead stakeholders or alter contractual outcomes. ${ }^{2}$ Most of those studies focus on managers pushing the boundaries of GAAP by exercising discretion over

\footnotetext{
${ }^{1}$ Although the enhanced internal control evaluation and CEO/CFO certification requirements of SOX likely affected a manager's mindset regarding earnings management, like Cohen et al. (2008), we recognize that concurrent events could have contributed to a change in earnings management strategies. We similarly emphasize the role of SOX and refer to the "post-SOX" period but acknowledge that investor skepticism following the accounting scandals and regulatory scrutiny and enforcement actions could help to explain our results.

${ }^{2}$ See Schipper (1989) and Healy and Wahlen (2000) for further discussion and review of literature.
} 
the accrual component of earnings. This manipulation obfuscates to some extent the informational value of accounting estimates and judgments embedded in accruals that otherwise provide a better reflection of economic events and a better signal of future profitability

(Subramanyam 1996; Xie 2001). Alternatively, the real earnings management literature suggests that managers opportunistically affect reported earnings through certain operating, investing and financing decisions to obtain some short-term benefit (Bartov 1993, Roychowdhury 2006, Cohen and Zarowin 2010, Zang 2012). These transactions or activities presumably deviate from what otherwise would be a value maximizing strategy. In support of that view, Graham, Harvey and Rajgopal (2005) survey over 400 chief financial officers (CFOs) and document their willingness to sacrifice long-term value in order to avoid the immediate stock market penalty that results from reporting lackluster earnings.

Cohen et al. (2008) contend that a rash of accounting scandals (e.g., Enron, Adelphia Communications and Worldcom) and greater regulatory oversight that culminated in the 2002 passage of SOX increased the marginal cost of opportunistic AEM. The increased threat of penalties and reputational costs associated with detection of accounting manipulations disrupted the equilibrium that existed between AEM and REM prior to SOX. In response, they suggest that firms turned to more opaque and more defensible REM activities. ${ }^{3}$ In addition, Zang (2012) models the trade-off between REM and AEM more generally argues that heightened regulatory scruitiny at this time made AEM more costly. However, their analysis stops short of considering the implicit costs associated with relatively greater REM. Thus, in contrast to these studies that consider how SOX alters the relative costs of earnings management strategies, we focus on the

\footnotetext{
${ }^{3}$ Survey responses in Graham et al. (2005) clearly indicate a preference for REM over AEM in the post-SOX era. Specifically, subjects express agreement (disagreement) with altering real activities (accrual estimates/assumptions) to hit an earnings target. In subsequent interviews, CFOs reasoned that real earnings management is less susceptible to challenge.
} 
economic implications of these activities before and after SOX. That is, rather than explain or control for the trade-off of REM and AEM, we examine the consequences of that trade-off. It stands to reason that managers choosing to ratchet up the level of REM after SOX would face even more difficult choices in order to have the same effect on short-term earnings. That is, managers must take more drastic measures that are more costly to long-run value relative to preSOX. Thus, we contend that the shift in earnings management strategies in response to this exogenous shock is not innocuous.

The objective of our study is to investigate how the substitution of REM for AEM after the passage of SOX affects the typical firm. We begin by directly examining the relation between REM and future firm performance pre- and post-SOX. If the increase in REM reflects an increase in opportunistic behavior with managers being confronted with more difficult and costlier choices, we expect post-SOX REM to be associated with lower levels of future profitability relative to pre-SOX REM. Likewise, if investors perceive that the increase in REM reflects a greater willingness by managers to sacrifice long-term value, we should observe a corresponding decrease in the value relevance of that activity. Of course, investors may have difficulty discerning opportunistic REM from normal business operations, in which case prices might not reflect an increase in myopic behavior.

Additionally, we examine whether the post-SOX decrease in discretionary accrual activity is consistent with less AEM by examining how those accruals map to future performance. If in fact discretionary accruals are less tainted by managerial manipulation, then the relative quality of discretionary accruals should improve. Thus, the relation between discretionary accruals and future performance should increase after SOX. If investors recognize the increase in accrual quality, the value relevance of those accruals should increase as well. This 
implies a stronger market reaction to discretionary accruals post-SOX. However, evidence in prior studies suggesting that investors tend to overestimate the earnings persistence of accruals (Sloan 1996; Xie 2001) complicates how the actual relation with returns might change. If less accrual manipulation coupled with greater reporting transparency following SOX contribute to more efficient pricing of discretionary accruals, market prices might be less prone to an initial overreaction.

To test our predictions, we split our sample period into pre- and post-SOX regimes. We define the pre-SOX period as 1990-2001 and the post-SOX period as 2003-2012. We select a broad cross-section of firms to capture the on-average effects of AEM and REM across a range of incentives for earnings management. While earnings management may be more evident for a contextual subset of firms with a particular incentive to manage earnings (e.g., avoiding debt covenant violation, meeting analyst expectations or boosting compensation), we suspect that the specific conditions giving rise to that incentive will strongly influence the relations with future performance..$^{4,5}$

To capture real earnings management activities, we follow Roychowdhury (2006) and estimate abnormal levels of cash flow from operations, discretionary expenses, and production costs. We estimate discretionary accruals following McNichols (2002) and assess future operating performance using return on assets (ROA) over the subsequent three years. As expected, we find that real earnings management activities in the post-SOX period are associated with lower levels of future ROA than in the pre-SOX period. This suggests an increase in

\footnotetext{
${ }^{4}$ For example, earnings management to avoid debt covenant violations likely benefits shareholders and leads to higher future earnings than if the firm did not manage earnings. The same cannot be said of managers inflating current earnings to boost their compensation.

${ }^{5} \mathrm{We}$ acknowledge that in a broader sample, our earnings management proxies might be capturing other effects. In supplemental analysis, we also discuss results for a set of "suspect" firms that avoid an earnings decline by a small amount. Results for this subset of firms also support our hypotheses, although relations with stock returns are sensitive to the return measure.
} 
myopic behavior, i.e., operating decisions that boost short-term earnings but adversely impact future performance. We also find results consistent with our predictions about discretionary accruals. Specifically, we find that the relation between discretionary accruals and future firm performance is more positive post-SOX. This suggests a reduction in accrual manipulation and an increase in the relative quality of accruals.

Consistent with our evidence that real earnings management after SOX leads to relatively lower levels of future ROA, we also find that it corresponds to relatively lower stock returns. This market-based test supports the view that the shift toward real earnings management reduces firm value. Further, the weaker contemporaneous return relation suggests that investors recognize to some extent the increase in opportunistic real earnings management activities. With respect to discretionary accruals, we find that their ability to predict future earnings improves after SOX, consistent with greater accrual quality. In addition, our return analysis points to less accrual mispricing (i.e., less overreaction) in the post-SOX period. We find that the contemporaneous market response to discretionary accruals decreases after SOX and future price reversals essentially disappear. The return results are consistent with both less accrual manipulation by managers (Cohen et al 2008) and greater awareness of opportunistic accruals by investors (Gavious and Rosenboim 2013). Our evidence that the relation between discretionary accruals and future ROA strengthens after SOX clearly supports the former explanation, but it is also plausible that investors take a more skeptical view of discretionary accruals in the post-SOX period and discount them accordingly.

Finally, we consider the net effect of the shift in earnings management tactics. If real earnings management imposes greater economic costs on a firm than accrual manipulation, then the negative effects of increased real earnings management activities could more than offset any 
economic benefits associated with less accrual management. To better illustrate the economic significance of these effects, we independently assign observations to quintiles based on real and accrual earnings management and compare firm performance in the pre- and post-SOX periods. Prior to SOX, moving from the bottom to the top quintile of real earnings management results in a 1 percent reduction in future ROA, but after SOX that grows to a 19.9 percent reduction in future ROA. Meanwhile, moving from the bottom to the top quintile of discretionary accruals results in a 7 percent decrease in future ROA before SOX but a 6.1 percent increase after SOX. Comparing the changes from pre- to post-SOX periods, the 18.9 percent decrease in future performance related to real earnings management activities more than offsets the 13.1 percent improvement related to discretionary accruals, suggesting a net negative impact on future profitability. Likewise, the negative stock price effect associated with the increase in real earnings management after SOX significantly outweighs the beneficial effect of higher quality discretionary accruals. Finally, we examine the joint effects of real and accrual earnings management and find that in the post-SOX period a combination of the two strategies is associated with both lower future profits and stock returns relative to the pre-SOX period. These results suggest that the shift in earnings management strategies that accompanied SOX had an overall detrimental effect on firm future performance and firm value.

This study makes several contributions to existing research. First, the study extends real earnings management research by showing that the post-SOX increase in real activities manipulation documented by Cohen et al. (2008) is consistent with managers making more drastic choices to trade-off long-term value for short-term earnings. Further, it appears that investors partially recognize and price this myopic behavior after SOX. Second, we add to extensive literature examining the quality and pricing of accruals by showing that the post-SOX 
decrease in discretionary accruals results in higher quality accruals (i.e., a stronger relation to future ROA). Similar to Green et al. (2015), our results suggest that the subsequent return reversal typically associated with discretionary accruals largely disappears after SOX. However, unlike their study, our results suggest that investors put less weight on discretionary accruals in the current period. Most importantly, our study brings these separate analyses together to extend research investigating the impact of SOX. We find that the resulting shift in earnings management strategies corresponds to a net negative effect in terms of future accounting performance and firm value, consistent with greater economic costs of real earnings management relative to accrual management. This points to potential unintended consequences of SOX that run counter to the overriding objective of enhanced financial reporting quality.

The next section of the paper discusses background literature and develops our hypotheses. Section 3 describes our earnings management proxies and sample, and Section 4 presents the results of our analysis. The paper concludes with Section 5.

\section{Background and hypotheses}

2.1 Real earnings management literature

In a well-recognized survey of corporate CFOs, Graham et al. (2005) report that a clear majority of executives would alter real activities, including delaying discretionary expenditures or positive NPV projects, in order to meet an earnings target. ${ }^{6}$ Alternatively, executives expressed a reluctance to modify accounting assumptions, even if those actions are within GAAP. Graham et al. explore this issue in follow-up interviews with respondents who note that unlike accounting policies, auditors have little basis for challenging real business decisions that

\footnotetext{
${ }^{6}$ Of the CFOs surveyed, $80 \%$ (55\%) agree or strongly agree with reducing discretionary spending on advertising, $\mathrm{R} \& \mathrm{D}$ or maintenance (delaying a new project that entails a small sacrifice in value).
} 
are objectively measured and recorded. However, CFOs fear that even legitimate accounting choices could be questioned by aggressive regulators in the current (post-SOX) environment. Perhaps more intriguing is managers' willingness to deviate from a value-maximizing path to deliver short-term earnings. Graham et al. conclude that most executives believe they are making an appropriate choice when sacrificing long-term economic value to avoid the immediate stock price turmoil associated with disappointing investors or creating uncertainty.

A number of archival studies examining various operating, investing and financing decisions find results consistent with real activities manipulation. These include curtailing discretionary expenditures such as research and development (R\&D) or advertising (Baber, Fairfield and Haggar 1991, Dechow and Sloan 1991, Bushee 1998), building up inventory to diffuse fixed production costs (Jiambalvo, Noreen and Shevlin 1997, Thomas and Zhang 2002), offering favorable terms to accelerate sales (Oyer 1998), and timing asset sales to accelerate gain recognition (Bartov 1993). Roychowdhury (2006) develops empirical proxies for the first three mechanisms and finds that they are strongly correlated with firms avoiding a loss. He also provides limited evidence that firms use these tactics to meet or beat analysts' earnings expectations, consistent with managers attempting to convince stakeholders that earnings targets have been met in the normal course of business. ${ }^{7}$

While the prior literature focuses on opportunistic incentives associated with REM activities, Gunny (2010) investigates the relation with future earnings. Specifically, she examines future ROA for firms using REM to avoid an earnings decline or a loss. Her evidence, based on a pre-SOX sample, suggests that firms using REM to just meet the target outperform those that

\footnotetext{
${ }^{7}$ Other evidence of opportunistic real earnings management includes Cohen, Mashruwala and Zach (2010), who find that firms reduce advertising to avoid quarterly earnings losses and earnings decreases. Alissa, Bonsall, Koharki, and Penn (2013) find that firms use income-increasing (-decreasing) real earnings management when they are below (above) their expected credit rating. Finally, Cohen and Zarowin (2010) suggest that firms use real earnings management prior to seasoned equity offerings, which contributes to post-SEO underperformance.
} 
miss as well as those that meet the target without REM. She concludes that, the short-term benefits from managing real activities either signal or contribute to future firm performance. While Gunny's (2010) findings based on relative firm performance provide context for managers' decisions to alter operating decisions, they are not necessarily inconsistent with the survey results of Graham et al. (2005) that REM sacrifices some degree of long-run value.

\subsection{Discretionary accruals literature}

A separate stream of literature examines how managers affect reported earnings through accruals. While accruals serve to compensate for timing and matching issues associated with cash flows (Wilson 1986; Bowen et al. 1987; Dechow 1994), managers exercise considerable judgment over their recognition and measurement. However, unlike REM, any accrual-based earnings management simply shifts accounting recognition between periods and should not directly affect a firm's fundamental economic value. ${ }^{8}$ Thus, AEM could be an effective short-run tool for managers to either inform or misinform stakeholders about firm prospects.

Subramanyam (1996) decomposes total accruals into nondiscretionary and discretionary components and examines the market pricing of discretionary accruals. He concludes that managers use subjective judgment and estimation to signal or convey private information to investors about anticipated cash flows. ${ }^{9}$ Alternatively, numerous studies suggest that managers use discretionary accruals to mislead stakeholders for private benefit. For example, Healy (1985), Efendi et al. (2007), McAnally et al. (2008), Burns and Kedia (2006), and Bergstresser

\footnotetext{
${ }^{8}$ Although accrual manipulation does not directly alter the underlying cash flows, the revelation of accrual manipulation can erode investor confidence in the financial reporting process or prompt regulatory penalties or litigation that impose real costs on a firm. Additionally, accrual management can indirectly affect cash flows and decrease firm value by facilitating wealth transfers, e.g., inflating employee compensation.

${ }^{9}$ Other studies supporting the signaling view of discretionary accruals include Louis and Robinson (2005), Tucker and Zarowin (2006) and Linck, Netter and Shu (2013).
} 
and Philippon (2006) conclude that opportunistic managers use accrual earnings management to boost their compensation. ${ }^{10}$ Rather than communicating information to investors, these opportunistic accruals likely distort or garble the information in earnings. ${ }^{11}$ To the extent that investors are misled by opportunistic accruals, stock prices could deviate from fundamental values in predictable directions. In particular, Sloan (1996) suggests that investors overestimate the implications of accruals for future earnings and prices subsequently correct as future earnings are realized. Xie (2001) shows that this anomaly is driven by the more discretionary portion of accruals. Thus, in contrast to the signaling view discussed above, the "accrual anomaly" research suggests that the market overreacts to discretionary accruals leading to short-run price distortions and future price reversals. Moreover, researchers often use the negative relation between discretionary accruals and future returns as an indication of AEM (e.g., Teoh, Welch and Wong 1998; Louis 2004; and Cohen and Zarowin 2010).

\subsection{Implications of SOX}

In the wake of several high-profile financial reporting scandals such as Enron and WorldCom, the U.S. Congress passed the Sarbanes-Oxley Act of 2002 to protect investors from the possibility of fraudulent accounting activities. The main objectives of SOX were to improve the corporate governance of US traded firms, increase the accuracy and reliability of corporate disclosures, and restore investors' confidence in U.S. capital markets. Several recent studies suggest that SOX has been effective to some extent in achieving these objectives. For example, Ashbaugh-Skaife et al. (2009) find that the mandated reporting of internal control deficiencies

\footnotetext{
${ }^{10}$ Evidence that career concerns and penalties appear to moderate this behavior (Petroni 1992, Mergenthaler et al. 2009, Ahmed et al. 2011, and Defond and Park 1997) further suggest that managers exercise discretion over accruals in their own self-interest.

${ }^{11}$ Jayaraman (2008) provides evidence that bid-ask spreads and the probability of informed trading increase when earnings are smoother than cash flows, consistent with accruals garbling publicly available information.
} 
explains variation in cost of equity, and Bargeron et al. (2010) concludes that enhanced corporate governance associated with SOX discouraged risk taking by publicly traded U.S. firms. Further, Jain et al. (2008) find improvement in long-term market liquidity, and Brochet (2010) suggests that disclosures required by SOX reduced incentives for insiders to sell on private information.

Focusing specifically on earnings management activities, Cohen et al. (2008) document that after the passage of SOX, AEM decreased but REM increased. They argue that greater scrutiny of accounting manipulations by auditors and regulators motivated opportunistic managers to turn to REM as a means of boosting earnings. In a comprehensive investigation of various costs affecting the earnings management choice, Zang (2012) also finds that SOX is associated with a decrease (increase) in AEM (REM). ${ }^{12}$ In contrast to these studies that consider how SOX alters the relative costs of earnings management strategies, we focus on the economic implications of these activities before and after SOX. That is, rather than explain or control for the trade-off of REM and AEM, we examine the consequences of that trade-off.

Building on prior research, we argue that a greater reliance on real activities manipulation after SOX forces managers to take more drastic operational measures, relative to pre-SOX. For example, an opportunistic manager prior to SOX might cut back on marginal R\&D projects and adjust certain accrual estimates to inflate current earnings. In the post-SOX environment, greater reluctance to manipulate accruals would likely necessitate cutting more promising R\&D projects (or some other form of REM) to have the same effect on earnings. We essentially argue that the low-hanging fruit had already been picked. Thus, we posit an increasing marginal cost of real activities manipulation, whereby an additional dollar of REM implies a greater sacrifice of future

\footnotetext{
${ }^{12}$ In a similar vein, Ewert and Wagenhofer (2005) show analytically that tightening accounting standards (i.e., more rules-based) increases the cost of accrual manipulations and increases the marginal benefit of REM. Also, several studies suggest that monitoring by high quality auditors constrains the ability to manage accruals causing firms to resort to real earnings management techniques (Chi et al. 2011 and Burnett et al. 2012).
} 
performance. Consistent with an overall increase in real activities manipulation after SOX, we predict that REM for the average firm will be less indicative of future earnings relative to preSOX. This leads to our first hypothesis stated below in the alternative form.

\section{H1: The relation between real earnings management activities and future firm performance decreases after SOX.}

We note that any economic benefits associated with "delivering earnings" via greater REM (Gunny 2010) in the post-SOX period could offset the sacrifice of future performance and work against us finding support for our hypothesis. Likewise, if managers increase REM to signal future performance rather than for opportunistic reasons, the relation between REM and future firm performance could strengthen after SOX, resulting in a failure to reject $\mathrm{H} 1$.

As an extension to $\mathrm{H} 1$, we also consider how market participants respond to this shift in earnings management strategies. Consistent with post-SOX REM conveying less information about future firm performance, it stands to reason that income arising from this activity would be less value relevant to investors. Thus, we expect that the relation between REM and stock returns also decreases after SOX. If greater levels of REM in the post-SOX environment imply that managers sacrifice even more long-term value for short-term benefit than in the pre-SOX environment, investors should discount this activity to a greater extent. However, even if we find support for $\mathrm{H} 1$, outsiders might have difficulty distinguishing opportunistic decisions from value maximizing decisions. ${ }^{13}$ Thus, our second hypothesis, which follows, represents a joint test of the economic implications and investor recognition of the behavior.

H2: $\quad$ The relation between real earnings management activities and stock returns decreases after SOX.

\footnotetext{
${ }^{13}$ In addition, real earnings management typically does not violate generally accepted accounting principles, so auditors have little reason to flag such activity.
} 
If investors immediately recognize the trade-off of long-term value, we would expect to observe a change in the relation between real earnings management and contemporaneous returns. Alternatively, if investors recognize the value-decreasing effects when the firm eventually reports disappointing earnings, we would expect to observe a shift in the relation between real earnings management and future stock returns, consistent with a price correction. Although we do not formulate distinct hypotheses regarding contemporaneous and future returns, we examine the separate relations in our analysis.

Cohen et al. (2008) also document that while discretionary accruals increase steadily from 1987 to 2001, they decrease after the passage of SOX. This trend is primarily driven by income increasing accruals. Zhou (2008) also finds that both signed and unsigned discretionary accruals decrease post-SOX. Evidence of reduced discretionary accruals could be seen as fulfilling a major goal of SOX to restore investor confidence by focusing auditor attention on questionable accounting practices and making it more difficult and costly to manage earnings using accruals. In a concurrent study, Green et al. (2015) examine the pricing of discretionary accruals over time and conclude that accrual mispricing decreases and value relevance increases after SOX. They interpret their results as evidence that overall accrual quality has improved; however, they do not directly link discretionary accruals to future accounting measures of performance. Our study addresses that issue by considering how the relation between discretionary accruals and future performance changes after SOX.

We assume that a given firm's discretionary accruals include a mix of opportunistic accrual manipulations and informative estimates and judgments. A reduction in uninformative opportunistic accruals after SOX should lead to an increase in the relative proportion of informative discretionary accruals. Further, the opportunistic component constitutes accrual error 
that must eventually reverse (Allen et al. 2013; Dechow et al. 2012). Therefore, a reduction in opportunistic manipulation implies less future earnings reversal per dollar of discretionary accruals. ${ }^{14}$ As we hypothesize below, the relation between discretionary accruals and future firm performance should be more positive post-SOX.

\section{H3: $\quad$ The relation between discretionary accruals and future firm performance} increases after SOX.

In addition to the relation between discretionary accruals and accounting performance, we also investigate the market's pricing of discretionary accruals pre- and post-SOX. Following Green (2015), we expect that an increase in accrual quality should lead to a more positive relation to stock returns. However, other factors could serve to temper a stronger price reaction. First, if investors overreact to discretionary accruals prior to SOX, the per unit price response would be greater than warranted (Xie 2001). If the proportion of low quality accruals declines after SOX, a previously excessive price response might now be more appropriate, resulting in little or no change. Second, attention to scandals and the passage of SOX could alter investor perceptions of discretionary accruals irrespective of any change in accrual quality. If SOX increased investor awareness of accrual manipulation (Gavious and Rosenboim 2013), it is plausible that the market views discretionary accruals with greater skepticism in the post-SOX period. Thus, investors might discount discretionary accruals to a greater extent even if overall quality improves. These factors, which are not mutually exclusive, work against finding support for our fourth hypothesis.

\footnotetext{
${ }^{14}$ For example, a positive accrual reflecting earnings management will increase return on assets in period t; however, it will reverse in a future period with no corresponding cash flow, leading to a negative relation with future earnings. Alternatively, a positive accrual that signals future growth also increases return on assets in period t. However, it also correctly anticipates future benefits such that when the accrual reverses, it is replaced by a realized cash flow.
} 


\section{H4: $\quad$ The relation between discretionary accruals and stock returns increases after}

SOX.

To provide additional insight on these issues, we examine how both contemporaneous and future return relations with discretionary accruals change after SOX. In particular, we expect that less accrual mispricing after SOX would manifest in less of a future price reversal.

Finally, we examine the net effects of the shift away from AEM in favor of REM. Consistent with Cohen et al. (2008) we speculate that REM, which alters cash flows in a nonvalue-maximizing way, is costlier than AEM, which simply shifts income recognition from one period to another. Thus, the predicted improvement in discretionary accrual quality, could be more than offset by managers' willingness to sacrifice long-term value through greater REM. Alternatively, recent research suggests that firms use less earnings management after SOX to meet earnings benchmarks (Koh et al. 2008; Bartov and Cohen 2009, Gilliam et al. 2014). In addition, Lobo and Zhou (2006, 2010) find that firms report more conservatively in the postSOX period. Thus, if the decline in AEM outpaces the increase in REM, the economic benefits of less accrual manipulation after SOX could exceed the incremental costs of greater real activities manipulation. Given the inherent uncertainty surrounding these events, we refrain from stating formal hypotheses and address this question as additional analysis.

\section{Variable measurement and sample}

\subsection{Earnings management proxies}

To test our hypotheses, we follow Roychowdhury (2006) and identify deviations from the normal levels of cash flows from operations, discretionary expenditures, and production costs as REM proxies. Abnormal cash flows from operations arise from efforts to accelerate the timing of 
sales and/or generate unsustainable sales through discounts and more lenient credit terms. These additional sales boost current period earnings; however, the additional sales fail to generate a commensurate level of cash flows. ${ }^{15}$ Abnormal discretionary expenditures arise when research and development; selling, general, and administrative; and advertising spending levels deviate from what would be expected based on sales revenue. Reducing these expenses directly increases the current period's earnings and likely increases current cash flows. ${ }^{16}$ Abnormal production costs arise when firms overproduce in order to report a lower cost of goods sold and higher net income. In this case, managers produce more units of inventory to spread the fixed overhead costs over a larger number of units, thereby lowering fixed costs per unit. If the decrease in fixed overhead costs per unit is larger than the increase in variable cost per unit from the increased production, the total cost per unit and cost of goods sold decline. In addition, product costs can be relatively high if firms offer sales discounts to stimulate revenue. Thus, abnormal production costs captures elements of REM for both manufacturing and non-manufacturing firms.

We estimate the normal levels of the activities discussed above by year and industry using the Fama-French 48 industry classification codes. This allows the coefficients to vary across time while controlling for industry-wide changes in economic conditions that could affect operations. First, we estimate normal cash flows as a linear function of sales and change in sales using the following cross-sectional model:

$$
\frac{\text { CFO }_{i t}}{\text { Assets }_{i, t-1}}=\alpha_{1} \frac{1}{\text { Assets }_{i, t-1}}+\beta_{1} \frac{\text { REV }_{i t}}{\text { Assets }_{i, t-1}}+\beta_{2} \frac{\Delta R E V_{i t}}{\text { Assets }_{i, t-1}}+\varepsilon_{i t}
$$

\footnotetext{
15 This assumes that the sales discounts do not result in a negative profit margin.

${ }^{16}$ Current cash flows will increase to the extent that the foregone expenditure would have been paid in cash. This illustrates a limitation of the abnormal cash flow proxy in that other REM mechanisms could lead to positive rather than negative abnormal cash flows.
} 
where $C F O_{i t}$ is operating cash flow for firm $i$ in year $t, R E V_{i t}$ is revenue, and Assets $s_{i, t-l}$ is lagged total assets. Abnormal cash flows $\left(A \_C F O_{i t}\right)$ are measured as the residual from equation (1). Lower values of $A_{-} C F O_{i t}$ correspond to income increasing earnings management.

We similarly measure the normal level of discretionary expenses by industry and year as a linear function of sales as follows:

$$
\frac{\operatorname{DISCX}_{i t}}{\operatorname{Assets}_{i, t-1}}=\alpha_{1} \frac{1}{\operatorname{Assets}_{i, t-1}}+\beta_{1} \frac{\operatorname{REV}_{i t-1}}{\operatorname{Assets}_{i, t-1}}+\varepsilon_{i t}
$$

where $D I S C X_{i t}$ represents the sum of discretionary expenses related to research and development, advertising, and selling, general, and administrative expenses. Consistent with Roychowdhury (2006), we use the lagged value of sales revenue to avoid any potential mechanical problems if current sales are managed upward, which would result in significantly lower residuals when estimating equation (2). Residuals from equation (2) represent abnormal discretionary expenses $\left(A \_D I S C X_{i t}\right)$ with lower values implying income increasing earnings management.

Finally, we define total production costs as cost of goods sold $\left(C O G S_{i t}\right)$ plus the change in inventory $\left(\triangle I N V_{i t}\right)$ during the year. We assume that the normal level of $C O G S_{i t}$ is a function of sales and that the normal $\triangle I N V_{i t}$ is a function of current and lagged change in sales:

$$
\begin{aligned}
& \frac{\operatorname{COGS}_{i t}}{\operatorname{Asset}_{i, t-1}}=\alpha_{1} \frac{1}{\operatorname{Assets}_{i, t-1}}+\beta_{1} \frac{\operatorname{REV}_{i t}}{\operatorname{Asset}_{i, t-1}}+\varepsilon_{i t}, \\
& \frac{\Delta I N V_{i t}}{\operatorname{Assets}_{i, t-1}}=\alpha_{1} \frac{1}{\operatorname{Assets}_{i, t-1}}+\beta_{1} \frac{\Delta R E V_{i t}}{\operatorname{Assets}_{i, t-1}}+\beta_{2} \frac{\Delta \operatorname{REV}_{i, t-1}}{\operatorname{Assets}_{i, t-1}}+\varepsilon_{i t},
\end{aligned}
$$

Using equations (3) and (4), we estimate the normal level of production costs as the fitted value from the following model:

$$
\frac{\operatorname{PROD}_{i t}}{\operatorname{Assets}_{i, t-1}}=\alpha_{1} \frac{1}{\operatorname{Assets}_{i, t-1}}+\beta_{1} \frac{\operatorname{REV}_{i t}}{\operatorname{Assets}_{i, t-1}}+\beta_{2} \frac{\Delta R E V_{i t}}{\operatorname{Assets}_{i, t-1}}+\beta_{3} \frac{\Delta R E V_{i, t-1}}{\operatorname{Assets}_{i, t-1}}+\varepsilon_{i t},
$$

where $P R O D_{i t}$ is the sum of $C O G S_{i t}$ and $\triangle I N V_{i t}$. Abnormal production costs $\left(A \_P R O D_{i t}\right)$ are defined as the residual from equation (5), with greater values of $A \_P R O D_{i t}$ reflecting efforts to 
increase net income. To facilitate interpretation of the real earnings management proxies, we multiply $A \_C F O_{i t}$ and $A \_D I S C X_{i t}$ by negative one in our regression models so that greater values of these measures are also consistent with income increasing activity.

To proxy for AEM, we estimate discretionary accruals using the model from McNichols (2002), which combines the Jones (1991) and Dechow and Dichev (2002) models and controls for expected accrual reversals. Similar to the real earnings management proxies, we estimate the model annually by industry using the Fama-French 48 industry classification codes: ${ }^{17}$

$$
\begin{aligned}
\frac{\Delta W C_{i t}}{\text { Assets }_{i, t-1}=} & \alpha_{1}+\beta_{1} \frac{\Delta \text { REV }_{i t}}{\text { Assets }_{i, t-1}}+\beta_{2} \frac{P P E_{i t}}{\text { Assets }_{i, t-1}}+\beta_{3} \frac{\text { CFO }_{i t-1}}{\text { Assets }_{i, t-2}}+\beta_{4} \frac{\text { CFO }_{i t}}{\text { Assets }_{i, t-1}}+ \\
& \beta_{5} \frac{\text { CFO }_{i t+1}}{\text { Assets }_{i, t}}+\varepsilon_{i t},
\end{aligned}
$$

where $\Delta W C_{i t}$ represents the change in working capital (i.e., change in accounts receivable, change in inventory, change in accounts payable, change in taxes payable, and change in other assets) and $P P E_{i t}$ represents property plant and equipment. All other variables are defined above. The coefficients from equation (6) are used to estimate firm-specific normal accruals $\left(N A_{i t}\right)$, and our measure of discretionary accruals $\left(D A_{i t}\right)$ is the residual from equation (6).

\subsection{Sample description}

We draw our sample from the Compustat Annual Industrial and Research Files (COMPUSTAT) and the Center for Research in Security Prices (CRSP) data set for the period 1990-2012. As discussed, our analysis focuses on earnings management in two distinct subperiods that we identify as pre-SOX and post-SOX. Since the SOX was passed in 2002, we define the pre-SOX period as 1990-1998 and the post-SOX period as 2003-2012. We explicitly omit 1998 through 2002 from the analysis to cleanly partition the data and to avoid overlapping

\footnotetext{
${ }^{17}$ Results are qualitatively the same using the modified Jones (1991) model.
} 
the samples since we use variables for up to three years ahead (i.e., $t+3$ ) in our return on asset and security return measures. We also restrict our sample to nonfinancial firms with available data and require at least eight observations in each of the Fama-French 48 industry classifications. Our initial sample consists of 118,951 firm-year observations with sufficient data to estimate the real and accrual earnings management proxies. Data requirements to calculate control variables results in the loss of an additional 73,514 observations, resulting in 45,437 observations $(22,402$ pre-SOX and 23,514 post-SOX) from 7,802 unique firms.

\section{[Insert Table 1]}

Panel A of table 1 presents descriptive statistics for the sample. Following prior research, we winsorize continuous variables at the $1^{\text {st }}$ and $99^{\text {th }}$ percentiles to minimize the influence of outliers. For the main sample, the mean (median) of Assets (in millions) is 3,357.44 (208.78). The mean (median) value for the accrual earnings management proxy, $D A$, is $0.01(0.02)$. The mean (median) levels of the REM proxies are $0.01,0.00$, and $-0.03(-0.01,0.01$, and -0.09$)$ for $A \_C F O, A \_P R O D$, and $A \_D I S C X$, respectively. ${ }^{18}$

Panel B of table 1 presents the Pearson correlations of select variables. We note the positive relation between $A \_C F O$ and $A \_P R O D$, consistent with additional cash outflows from boosting income by overproducing. Likewise, the large positive correlation between $A \_C F O$ and A_DISCX likely reflects cash savings associated with increasing income by reducing discretionary expenditures. The correlation between $A \_D I S C X$ and $D A$ is also significantly positive, consistent with reductions in discretionary expenses increasing discretionary accruals as well as cash flows.

\section{Empirical analysis}

\footnotetext{
${ }^{18}$ The REM and discretionary accrual proxies are residuals from OLS regressions. Those models include all firms with available data for a given industry-year and not just our final sample firms. Accordingly, the means in Table 1 do not necessarily equal zero. Also note that results in Table 1 are after we multiply $A \_C F O$ and $A \_D I S C X$ by -1 .
} 
4.1 Real earnings management and future firm performance

To test $\mathrm{H} 1$, which considers whether the relation between real activities manipulation and future firm performance decreases post-SOX, we estimate equation (7) using OLS. We measure future performance using ROA in the three-year period following year $t$.

$$
\begin{aligned}
& R O A_{i, t+j}=\alpha+\beta_{1} R E M_{i t}+\beta_{2} T A_{i t}+\beta_{3} C F O_{i t}+\beta_{4} S G_{i t}+\beta_{5} S I Z E_{i t}+\beta_{6} M T B_{i t}+ \\
& \beta_{7} I N D \_R O A_{i t}+\beta_{8} R E T_{i t+j}+\beta_{9} S O X_{i t}+\beta_{10} R E M_{i t} * S O X_{i t}+\beta_{k} \text { Controls }_{i t} * S_{O X}+ \\
& \varepsilon_{i t+1}
\end{aligned}
$$

where $R O A_{i, t+j}$ is income before extraordinary items deflated by total assets and $j=1$ to $3 . R E M_{i t}$ represents one of three real earnings management proxies: $A \_C F O_{i t}, A_{-} P R O D_{i t}$, or $A \_D I S C X_{i t}$. To control for persistence in ROA, we include period t income, broken down into total accruals $\left(T A_{i t}\right)$ and $C F O_{i t}$, both scaled by $A_{s s e t s_{i, t-1} .} T A_{i t}$ is as defined as earnings before extraordinary items and discontinued operations less $C F O_{i t}$. We also include sales growth $\left(S G_{i t}\right)$, the natural $\log$ of total assets $\left(S I Z E_{i t}\right)$ and the market to book ratio $\left(M T B_{i t}\right)$ to control for growth opportunities and size effects. We include the industry return on assets $\left(I N D \_R O A_{i t}\right)$ using the Fama-French 48 industry classification codes to control for mean reversion of ROA and time series properties of firm performance. Finally, we include future compounded stock returns $\left(R E T_{i t+j}\right)$ to control for new value relevant information that is also captured in future ROA (Kothari and Sloan 1992). SOX $i t$ is a dichotomous variable taking the value of 1 if an observation is post-SOX and zero otherwise, and $R E M_{i t} * S O X_{i t}$ is the interaction between the real earnings management proxy of interest and $S O X_{i t}$. We also interact $S O X_{i t}$ with each control variable, except year and industry indicators; for brevity, we identify these interactions as Controls it $^{*}$ $S O X_{i t}$ in the model above. 
The coefficient on REM $\left(\beta_{1}\right)$ in equation (7) captures the incremental effects on future profitability in the pre-SOX period. Gunny (2010) finds a positive relation between REM and future ROA for firms meeting an earnings threshold and infers that in this situation managers alter real activities to signal future firm performance (or obtain current benefits that enhance future performance). Although we do not make explicit predictions about the sign of the coefficient in our multivariate model, $\mathrm{H} 1$ predicts an increase in opportunistic manipulation of real activities after the passage of SOX, which adversely impacts future performance. Accordingly, we expect the interaction between $R E M$ and $S O X$ to be negatively associated with future $R O A$ (i.e., $\beta_{10}<0$ )

The results from estimating equation (7) are reported in Table 2, with each of the three REM proxies tabulated separately in Panels A, B, and C. The first column in each panel reports results using the three-year aggregate $\mathrm{ROA}\left(R O A_{t+1, t+3}\right)$ as the dependent variable, and the next three columns report the results for each year individually. ${ }^{19}$ We allow the number of observations for the individual year models to vary based on data availability, although we obtain comparable results when we use a constant sample. In Panel A, the coefficient on $A \_C F O$ is positive and significant, suggesting that in the pre-SOX period, firms use REM to signal or enhance future performance, consistent with Gunny (2010). However, in support of H1, the positive relation with future profitability weakens substantially after the passage of SOX. Specifically, the coefficient on the interaction between $A \_C F O$ and $S O X$ is negative and significant for cumulative $R O A_{t+1, t+3}(\mathrm{p}<0.01)$ and in each year $t+1, t+2$, and $t+3(\mathrm{p}<0.01)$. Thus, real earnings management activities post-SOX appear to reflect relatively more

\footnotetext{
${ }^{19}$ Three-year aggregate ROA is calculated as the sum of net income before extraordinary items over the three years scaled by assets from the beginning of $t+1$.
} 
opportunistic behavior (and relatively less signaling) than prior to SOX. The control variables exhibit expected relations with future ROA, although $M T B$ is insignificant.

[Insert Table 2]

Panel B reports the results for the abnormal production cost proxy. The coefficient on A_PROD is positive and significant in each regression, but the coefficient on the interaction between $A \_P R O D$ and $S O X$ is significantly negative for cumulative $R O A_{t+1, t+3}$ and in period $\mathrm{t}+1$, only. Thus, we provide evidence that the relation between future return on assets and abnormal production costs decreases after SOX. In panel C, $A \_D I S C X$ similarly exhibits a positive association with future ROA pre-SOX. As predicted, the coefficient on the interaction between $A \_D I S C X$ and $S O X$ is negative but only marginally significant for cumulative $R O A_{t+1, t+3}$ and is negative and significant at the 5 percent level for period $t+1$.

In summary, we find fairly strong evidence in support of $\mathrm{H} 1$ with all three of the REM proxies. That is, as firms shift toward using more REM after SOX, they appear willing to sacrifice more future profits in the process. This is consistent with opportunistic managers interested in boosting income being confronted with more difficult choices resulting in more severe consequences for future performance.

4.2 Real earnings management and returns

Related to $\mathrm{H} 2$, we estimate the following model using OLS:

$$
\begin{gathered}
R E T_{i, t+j}=\alpha+\beta_{1} \text { REM }_{i t}+\beta_{2} \text { TA }_{i t}+\beta_{3} \mathrm{CFO}_{i t}+\beta_{4} S G_{i t}+\beta_{5} \mathrm{SIZE}_{i t}+\beta_{6} \mathrm{MTB}_{i t}+\beta_{7} \mathrm{SOX}_{i t}+ \\
\beta_{8} \mathrm{REM}_{i t} * \mathrm{SOX}_{i t}+\beta_{k} \text { Controls }_{i t} * \mathrm{SOX}_{i t}+\varepsilon_{i t+1}
\end{gathered}
$$

where $R E T_{i, t+j}$ is defined as the 12-month abnormal return. To control for risk factors that could affect returns, we estimate abnormal returns based on the Fama-French three-factor model 
$\left(A R_{j, t}=R_{j, t}-\left(\alpha_{j}+\beta_{1} R_{m k t}+\beta_{2} H M L+\beta_{3} S M B\right)\right)$. We estimate model parameters over a one-year period ending six months prior to the start of the return accumulation period. ${ }^{20}$ All other variables are defined above. We test $\mathrm{H} 2$ using four-year returns, $t$ though $t+3$, but we also estimate the model separately using contemporaneous returns, $j=0$, and future returns, $j=1$ to 3 to assess the timeliness of the market reaction.

To the extent that investors interpret REM as a favorable incremental signal of future performance as suggested by results in Table $2, \beta_{1}$ in equation (8) should be positive. However, if after SOX firms engage in more opportunistic value-decreasing real activities manipulation, as hypothesized, the interaction between REM and SOX should be negatively related to stock returns. To the extent that the market promptly recognizes and partially discounts the increase in real activities manipulation, we would expect $\beta_{8}$ to be negative and significant in the contemporaneous returns model. On the other hand, if the market reaction is largely captured in future returns, it could suggest that investors have difficulty recognizing the increase in real activities management.

Results from estimating equation (8) are reported in Table 3 with each of the three proxies presented in a separate panel. ${ }^{21}$ The first column of each panel reflects the cumulative return model, $R E T_{t, t+3}$. In panel A, we find that $A \_C F O_{i t}$ is positively associated with $R E T_{t, t+3}$ during the pre-SOX period, consistent with investors recognizing and pricing the incremental information in abnormal cash flows about future earnings. In support of $\mathrm{H} 2$, the coefficient on $A \_C F O * S O X$ is negative and significant $(\mathrm{p}<0.01)$, indicating a weaker price reaction to REM in the post-SOX period. Panels B and C reveal similar findings with cumulative returns. In panel B (panel C), the coefficient on $A \_P R O D\left(A \_D I S C X\right)$ is positive and significant, while the

\footnotetext{
${ }^{20}$ Results are qualitatively the same using the Carhart (1997) four-factor model.

${ }^{21}$ Requiring return data reduces the sample size slightly compared to the ROA analysis. However, we obtain similar results if we estimate all models with a constant sample.
} 
coefficient on the interaction $A \_P R O D * S O X\left(A \_D I S C X * S O X\right)$ is negative and significant at the one percent level. In short, the price relations mirror the weaker relation with future profitability documented in Table 2. Therefore, all three panels provide support for $\mathrm{H} 2$; investors view the increase in REM after SOX as implying greater sacrifice of long-run value.

[Insert Table 3]

We next estimate equation (8) using returns for year $t, t+1, t+2$ and $t+3$, separately, and report those results in the second through fifth columns of each panel. In all three panels, we observe a positive relation between the REM proxy and contemporaneous returns $\left(R E T_{t}\right)$ prior to SOX, but that relation significantly weakens after SOX. This suggests to us that investors recognize and price to some extent the changing implications of managing real activities in the current period. Interestingly, the same pattern is also evident with $R E T_{t+1}$, i.e, a significant reduction in the return relation after-SOX. In two of the three cases, the effect in year $t+1$ appears stronger than that in year $t$. In addition, although the coefficient on the interaction term diminishes steadily after $t+1$ for A_CFO and A_DISCX, they continue to be negative and significant through $t+3$, implying some degree of delay in the market response. In addition, the interaction coefficient on A_PROD is not significant in period $t$ and is largest in $t+1$, suggesting that the market has a more delayed response for abnormal production than for the other REM proxies.

In summary, we find evidence suggesting that, the shift towards more management of real activities after the passage of SOX reflects greater managerial opportunism, and investors at least partially recognize and price this change in behavior. Whereas in the pre-SOX period, REM is associated with a positive price reaction in $t$ and $t+1$, these relations attenuate considerably after SOX. 
4.3 Accrual earnings management and future firm performance

To test $\mathrm{H} 3$, we estimate the relation between discretionary working capital accruals and future ROA. We use the following model, which parallels equation (7):

$$
\begin{aligned}
R O A_{i, t+j}= & \alpha+\beta_{1} D A_{i t}+\beta_{2} T A_{i t}+\beta_{3} C F O_{i t}+\beta_{4} S G_{i t}+\beta_{5} S_{I Z E_{i t}}+\beta_{6} M T B_{i t}+\beta_{7} I N D_{-} R O A_{i t} \\
& +\beta_{8} R E T_{i t+j}+\beta_{9} S O X_{i t}+\beta_{10} D A_{i t} * S O X_{i t}+\beta_{k} \text { Controls }_{i t} * S O X_{i t}+\varepsilon_{i t+1}
\end{aligned}
$$

where $D A_{i t}$, is discretionary accruals, estimated using equation (6), and $T A_{i t}$ is total accruals. All other variables are as previously defined. If $D A_{i t}$ provides incremental information about future profitability, we would expect to observe a positive relation with ROA over the subsequent three years. Additionally, consistent with a reduction in accrual manipulation post-SOX, and therefore fewer earnings reversals attributable to accrual errors, $\mathrm{H} 3$ predicts a positive coefficient on the interaction between $D A$ and $S O X$ (i.e., $\beta_{10}>0$ ).

The results from estimating equation (9) are reported in Table 4. We find a negative coefficient on $D A_{i t}$ in the $R O A_{t+1, t+3}$ model, as well as each of the individual year models, indicating that discretionary accruals do not provide incremental information about future earnings in the pre-SOX period. We also find that the coefficient on the interaction term, $D A * S O X$, is positive and significant in each of the future ROA models, which supports $\mathrm{H} 3$. This suggests that in the post-SOX period, the earnings effect of an accrual in period t is less likely to reverse in a subsequent period. Overall, our results support the view that AEM decreases after SOX, and the relative quality of accruals increases on average.

[Insert Table 4]

4.4 Accrual earnings management and returns 
We next examine whether the market's perceptions of discretionary accruals change after SOX as hypothesized in H4. We estimate the following return model similar to equation (8):

$$
\begin{gathered}
\operatorname{RET}_{i, t+j}=\alpha+\beta_{1} D A_{i t}+\beta_{2} T A_{i t}+\beta_{3} C F O_{i t}+\beta_{4} S G_{i t}+\beta_{5} S I Z E_{i t}+\beta_{6} M T B_{i t}+\beta_{7} S O X_{i t}+ \\
\beta_{8} D A_{i t} * S O X_{i t}+\beta_{k} \text { Controls }_{i t} * S O X_{i t}+\varepsilon
\end{gathered}
$$

Based on the discretionary accruals pricing literature (Subramanyam 1996), we expect the main effect of $D A$, reflecting the pre-SOX relation, to be positive. The coefficient on the interaction, $D A * S O X$, captures any change in the incremental pricing of $D A$ after SOX. $\mathrm{H} 4$ predicts a positive value for $\beta_{8}$, corresponding to greater accrual quality documented in Table 4. However, as discussed above, prior evidence of accrual mispricing coupled with heightened sensitivity to accrual manipulation post-SOX (Gavious and Rosenboim 2013) complicates this relation.

We show the results from estimating equation (10) in Table 5. The first column reports results using $R E T_{t, t+3}$ as the dependent variable. Consistent with Subramanyam (1996), we find a positive association between discretionary accruals and long-term stock returns in the pre-SOX period. However, despite our evidence in Table 4 that accrual quality improves after SOX, we find that the incremental relation with long-term returns does not increase. That is, while we observe a positive coefficient on $D A * S O X$, it is not significant. In light of prior research concluding that investors initially overreact to discretionary accruals (Xie 2001), the market reaction after SOX is more consistent with higher quality accruals than greater investor skepticism of discretionary accruals and/or less mispricing. In other words, the effect of better accrual quality possibly offsets the effect of more efficient accrual pricing post-SOX.

[Insert Table 5]

Our separate analysis of contemporaneous and future stock returns provides further evidence of a reduction in mispricing. The results for $R E T_{t}$ are reported in column 2, and results 
for $R E T_{t+1}$ through $R E T_{t+3}$ are reported in the last three columns. The pre-SOX relation captured by $\beta_{1}$, reveals a strong positive relation between $D A$ and returns in year $t$ but a strong negative relation with returns in $t+1$. This fits with the accrual anomaly research concluding that investors initially overreact to discretionary accruals and prices subsequently correct. $\beta_{8}$ reflects the change in the post-SOX period and indicates a much smaller initial market reaction and less of a subsequent price reversal. The interaction term $D A * S O X$ is negative and significantly associated with returns in year $t(\mathrm{p}<0.01)$ and positive and significantly (marginally) associated with returns in $t+1(t+2)$. Further, the sum of $\beta_{1}$ and $\beta_{8}$ in the $R E T_{t+1}$ and $R E T_{t+2}$ models are insignificant, indicating that the price reversal essentially disappears after $\mathrm{SOX}^{22}$

In summary, we find evidence suggesting that firms engage in less accrual manipulation and that the market more efficiently prices discretionary accruals post-SOX. Improved accrual quality is supported by an increase in the relation between discretionary accruals and future ROA in the post-SOX period. The weaker contemporaneous market response (and disappearance of a return reversal) suggests that the reduction in accrual mispricing dominates the price implications of improved accrual quality.

\subsection{Net effects of earnings management after SOX}

Finally, to examine the net effects of the shift in earnings management tactics after SOX and to better illustrate the economic significance, we examine changes in performance (accounting and market) associated with portfolios of real and accrual earnings management. Specifically, in each sample year we independently rank firms based on real and accrual earnings

\footnotetext{
${ }^{22} \operatorname{In} t+1,-0.196+0.165=-0.031(\mathrm{t}$-statistic $=-1.04)$, and in $t+2,-0.018+0.011=-0.007(\mathrm{t}$-statistic $=-0.66)$.
} 
management and assign them to quintiles. ${ }^{23}$ We calculate the mean $R O A_{t+1, t+3}$ for each quintile and quantify the economic effect of each earnings management strategy by subtracting quintile 1 from quintile 5, designated by the superscripts Low and High, respectively. ${ }^{24}$, We do this separately for the pre-SOX period and the post-SOX period and compute the difference-indifferences for each form of earnings management. By identifying top and bottom quintiles separately in the pre- and post-SOX periods, we capture changes in the distributions of $R E M$ and $D A$ as a result of SOX and assess the implications of these changes for future earnings and stock returns. We anticipate greater inter-quintile variation in REM after SOX and correspondingly greater variation in firm performance. Consistent with our earlier results, we expect that the future ROA related to real activities management $\left(R E M^{H-L}\right)$ will be more negative after SOX, while the future ROA related to accrual management $\left(D A^{H-L}\right)$ will be more positive after SOX. Comparing the decrease associated with REM and the increase associated with AEM provides insight into the net earnings management effect at this time.

Table 6 includes the earnings management portfolio analysis of future ROA, with preSOX data in Panel A and post-SOX data in Panel B. The first row (column) reflects the full sample conditional on the magnitude of accrual (real) earnings management. In the pre-SOX period, the difference in $\mathrm{ROA}_{t+1, t+3}$ between the top and bottom discretionary accrual quintiles, $D A^{H-L}$, is -0.04 (p-value $\left.<0.05\right)$. The difference for extreme real earnings management quintiles, $R E M^{H-L}$, is 0.01 (p-value $>0.10$ ). This is consistent with AEM playing a much greater role and imposing greater long-run costs than REM prior to SOX. However, in the post-SOX period $D A^{H-L}$ reverses to +0.03 (p-value $<0.05$ ), while $R E M^{H-L}$ grows to -0.09 (p-value $<0.01$ ),

\footnotetext{
${ }^{23}$ To split the sample into REM quintiles, we follow Cohen et al. (2008) and compute a comprehensive measure of REM by standardizing and summing the three separate proxies.

${ }^{24}$ The middle three quintiles are grouped together in the portfolio designated Med. Focusing on the differences in extreme quintiles assigned annually helps to alleviate any market-wide effects.
} 
consistent with improved accrual quality but more severe real activities manipulation.

Comparing the pre- and post-SOX differences, the greater negative impact of real earnings management $(-0.10)$ exceeds the improvement from discretionary accruals $(0.07)$, and the net difference (-0.03) is significant at the five percent level. ${ }^{25}$ Thus, using the top and bottom quintiles to capture the range of each earnings management approach, we infer that the substitution of REM for AEM after SOX entailed a net negative effect on future earnings.

[Insert Table 6]

The other rows (columns) report accrual (real) earnings management portfolios, controlling for the level of real (accrual) earnings management. The same general trends are observed after controlling for the other earnings management strategy, i.e., $D A^{H-L}$ becomes positive after SOX and $R E M^{H-L}$ becomes much more negative.

Finally, we examine how a joint strategy of real and accrual earnings management changes after SOX. That is, we compare firms identified as high for both types of earnings management to those identified as low for both types of earnings management in both the preand post-SOX periods. Specifically, we subtract the top-left cell from the bottom-right cell in each panel, i.e., $\left(D A^{H i g h} R E M^{H i g h}\right)$ - $\left(D A^{\text {Low }} R E M^{\text {Low }}\right)$. In the pre-SOX period, the difference is $0.01[(-0.09)-(-0.08)]$, but after SOX the difference increases to $-0.06[(-0.11)-(-0.05)]$. The post-SOX minus pre-SOX difference of -0.05 is significant at the five percent level, supporting the interpretation that a combined earnings management approach imposes greater economic costs after SOX.

Table 7 reports a similar portfolio analysis focusing on the four-year compounded return, $R E T_{t, t+3}$, instead of future ROA to investigate the net pre- and post-SOX implications for firm value. Consistent with Table 6, we find that the negative firm value effects associated with REM

\footnotetext{
${ }^{25}$ For real earnings management $(-0.09)-(-0.01)=-0.10$; for discretionary accruals $(0.03)-(-0.04)=0.07$.
} 
get much worse after SOX (-0.27). Alternatively, the firm value effects associated with $D A$ improve from pre-SOX to post-SOX (0.04). While we do not find a significant association between DA and long-term stock returns after sox in Table 5, these results provide evidence of a stronger relation between DA and long-term stock returns. ${ }^{26}$ Importantly, the negative REM relation more than offsets the positive $D A$ relation. The net of the two effects $(-0.23)$ is significant at the one percent level, suggesting that the price implications of more opportunistic real earnings management dominate. ${ }^{27}$ Further, more negative returns associated with real earnings management after SOX are observed regardless of the level of discretionary accruals. Alternatively, more positive returns from improvement in accrual quality are only observed for low levels of REM. This further illustrates the sensitivity of the discretionary accrual and stock return relation discussed above.

\section{[Insert Table 7]}

We next evaluate the joint price implications of real and accrual earnings management focusing on the top-left and bottom-right cells. Prior to SOX, we find that $\left(D A^{H i g h} R E M^{H i g h}\right)$ $\left(D A^{\text {Low }} R E M^{\text {Low }}\right)$ is $0.15[(0.03)-(-0.12)]$ over four years, but after SOX the difference decreases to $-0.05[(-0.08)-(-0.03)]$. Thus, comparing firms that more likely engage in both earnings management strategies to those less likely indicates that a combination of the two approaches yields significantly smaller returns after SOX (one percent level).

\footnotetext{
${ }^{26}$ The analysis in Table 5 uses OLS to estimate equation (10) for the full sample with a continuous measure of $D A$. The analysis in Table 7 focuses on mean returns for extreme $D A$ firms and does not assume linearity. In addition, equation (10) controls for earnings and other firm characteristics; Table 7 does not. To help reconcile these results, we re-estimate equation (10) using a binary measure of $D A$ and only those observations in the extreme quintiles. We code $D A=0$ for the bottom quintile, $D A=1$ for the top quintile, and drop the middle quintiles. We find that the coefficient on the interaction term $D A * S O X$ is positive and significant (p-value < 0.05 ) in this model. Further, if we define $D A$ as an ordinal variable corresponding to the quintile assignments for the full sample, the interaction term is positive but insignificant. Thus, we conclude that contrasting results in Tables 5 and 7 are attributable to research design differences, including sample composition and variable definition, rather than a failure to control for correlated factors.

${ }^{27}$ For real earnings management $(-0.18)-(0.09)=-0.27$; for discretionary accruals $(0.16)-(0.12)=0.04$.
} 
Overall, the results in Tables 6 and 7 confirm our earlier findings and highlight the economic significance by quantifying the range in accounting and market performance between the top to bottom quintiles of earnings management, we show that the net effect of the two earnings management relations do not completely offset. In particular, the negative implications of greater real earnings management in the post-SOX period outweigh the benefits of discretionary accrual improvement in terms of future profitability or firm value.

\subsection{Additional analyses}

Our sample intentionally includes a broad cross-section of firms rather than a more contextual sample of suspect firms in an effort to abstract away from the particular economic conditions that could incentivize firms to engage in earnings management. While this allows us to capture the on-average implications of alternative earnings management strategies, it is possible that REM and DA capture other effects besides earnings management. Despite our efforts to control for these effects in our model, those controls might be incomplete. Accordingly, we also examine a subset of firms that ex post more likely manage earnings. We identify 2,038 firm-year observations (1,250 pre-SOX and 933 post-SOX) with available data that avoid an earnings decline by less than 0.01 (earnings scaled by total assets) and repeat the return on assets and security return analysis. We tabulate the summary $\mathrm{ROA}_{t+1, t+3}$ regressions for each earnings management proxy.

\section{[Insert Table 8]}

In the first column of Panel A in Table 8, consistent with Table 4 and H3, we find a negative and significant coefficient on DA and a positive and significant coefficient on DA*SOX. Additionally, in columns 2-4, the REM proxies, A_CFO, A_PROD, and A_DISCX, 
are all positive and significantly associated with $\mathrm{ROA}_{t+1, t+3}$ in the pre-SOX period; however, all three of the interactions between the REM proxies and SOX are negative and significant at the one percent level, which is consistent with our earlier findings and prediction for $\mathrm{H} 4$.

In Panel B, we tabulate the three-year return on assets for suspect firms in the pre-SOX and post-SOX periods. The average ROA is negative for suspect firms pre- and post-SOX. Additionally, consistent with our findings in Table 6, we find that the difference in ROA from pre- to post-SOX (-0.05) is significant at the one percent level, suggesting that even though suspect firms are less likely (more likely) to use AEM (REM) post-SOX, they have lower future return on assets post-SOX.

We also tabulate summary our regression results for security returns, $\mathrm{RET}_{\mathrm{t}, \mathrm{t}+3}$, and suspect firms. In the first column of Panel A in Table 9, DA is positive and significant, consistent with our earlier findings; however, DA*SOX is also negative and significant, whereas DA*SOX was positive and insignificant in Table 5. This provides strong evidence that the market is pricing accruals more appropriately post-SOX for this subset of firms. Additionally, in columns 2-4, we find results consistent with Panels $\mathrm{A}, \mathrm{B}$, and $\mathrm{C}$ of Table 2, suggesting that firms engage in more opportunistic value-decreasing real activities manipulation post-SOX.

\section{[Insert Table 9]}

In Panel B, we tabulate four year returns for suspect firms in the pre- and post-SOX periods. The average return is positive and significant in the pre-SOX period and negative and significant in the post-SOX period. Additionally, the difference (Post-Pre) is negative and significant, consistent with the results from Table 7. This suggests that, although firms use less (more) AEM (REM) post-SOX, returns are significantly lower. 
Although we cumulate stock returns over several years, they reflect a "change" in firm value and are aimed at the market value of common equity as opposed to the current market value of the firm. As an alternative, we also use Tobin's q (Brainard and Tobin 1968), which captures the level of firm value. Tobin's q is defined as the ratio of the market value of equity plus long-term debt to the book value of equity plus long-term debt.

[Insert Table 10]

In Table 10, DA is negative and marginally significant in the pre-SOX period, while two of the three REM proxies are positive and significant. ${ }^{28}$ Meanwhile, DA*SOX remains positive and significant, suggesting higher accrual quality and less mispricing post-SOX, which is consistent with prior results. Additionally, also consistent with prior results, the interactions between two of the three REM proxies (A_CFO and A_PROD) and SOX are negative and significant suggesting more opportunistic earnings management behavior post-SOX. ${ }^{29}$

Finally, we examine the relation between earnings management activities of suspect firms pre- and post-SOX and the Altman (1968) ZSCORE. The ZSCORE is a formula that is used to predict the likelihood that a company could go into bankruptcy. Thus, we predict that firms suspected of engaging in earnings management activities post-SOX will have lower ZSCORES than firms suspected of earnings management in the pre-SOX.

\section{[Insert Table 11]}

For AEM, we find that DA is negatively associated with ZSCORE in the pre-SOX period, and the interaction on DA*SOX is positive and significant suggesting that firms suspected of AEM have a higher probability of bankruptcy during the pre-SOX period. We also find that all three REM proxies are positive and significant while the interactions on the REM

\footnotetext{
${ }^{28}$ DISCX is in the predicted direction but is not significant.

${ }^{29}$ DISCX*SOX is in the predicted directions but is only marginally significant.
} 
proxies and SOX are negative and significant, consistent with firms suspected of REM activities having a higher probability of bankruptcy during the post-SOX period. In untabulated analysis, we also find that firms suspected of EM in the post-SOX period have lower ZSCORES than they did in the pre-SOX period, as defined previously. These firms also exhibit lower ZSCORES when compared to the prior year. These findings are consistent with the negative implications of greater real earnings management in the post-SOX period outweighing the benefits of discretionary accrual improvement.

\section{Conclusion}

While prior research suggests that firms shifted away from accrual manipulation in favor of REM after the passage of the Sarbanes-Oxley Act of 2002 (Cohen et. al 2008), the economic effects of this switch for the typical firm remain unclear. This study examines how the relations between earnings management (real and accrual) and measures firm performance change with the advent of SOX. Our analysis supports the view that the increase in real activities management post-SOX is driven by opportunistic managers willing to forego greater levels of future profits. Specifically, we find that the positive relation between several REM proxies and future ROA weakens after SOX. This implies that managers find it necessary to sacrifice more long-term value when engaging in real activities manipulation. It also appears that investors recognize and price to some extent this change in behavior, suggesting that these trade-offs are more detrimental to firm value. In addition, our analysis of discretionary accruals pre- and postSOX reveals that their association with future ROA increases, consistent with improved accrual quality. Alternatively, the relation between discretionary accruals and stock returns suggests less mispricing after SOX, which is also consistent with better financial reporting transparency. Perhaps the most interesting part of our study is the investigation of the net economic 
implications. With respect to both future profitability and stock prices, we find that the adverse effects of REM after SOX outweigh the benefits of less AEM. This is also borne out by an examination of the joint effects of real and accrual earnings management, focusing on those firms that are high and low in both strategies. The combination results in greater economic costs in the post-SOX period than in the pre-SOX period.

We recognize that the study has some limitations. First, we cannot unequivocally attribute the above economic consequences to SOX, as several other concurrent developments could have contributed to the results. Therefore, our identification of pre- and post-SOX periods refers to the changing financial reporting climate at this time rather than specific features of the legislation. Additionally, there are inherent limitations in measuring earnings management. One limitation is that discretionary accrual models lack power and are often mispecified (Dechow et al. 2012). Third, while it is likely that managers can alter a number of different real activities to affect earnings, this study focuses on only three activities.

Despite the limitations noted above, the findings of this study provide unique insights concerning the fundamental objectives of SOX to curb earnings management and restore investor confidence. Even though accrual management decreased following SOX, the negative implications associated with the increase in real activities management post-SOX had a net negative effect on future performance and firm value. Thus, in the context of prior research identifying the numerous benefits of SOX, our results are consistent with potential unintended consequences that should be of particular interest to both investors and regulators. 


\section{Appendix A}

\section{Variable Definitions}

\begin{tabular}{|c|c|}
\hline$\Delta \mathrm{INV}$ & Change in inventory (annual Compustat data item 3) \\
\hline$\Delta \mathrm{WC}$ & $\begin{array}{l}\text { The change in accounts receivable (annual Compustat data item 302) plus } \\
\text { the change in inventory (annual Compustat data item 303) minus the } \\
\text { change in accounts payable (annual Compustat data item 304) minus the } \\
\text { change in taxes payable (annual Compustat data item 305) plus the change } \\
\text { in other assets (annual Compustat data item } 307 \text { ). }\end{array}$ \\
\hline A_CFO & $\begin{array}{l}\text { Actual CFO minus normal CFO, where CFO is operating cash flows and } \\
\text { normal CFO is the fitted value from equation (1). }\end{array}$ \\
\hline A_DISCX & $\begin{array}{l}\text { Actual discretionary expenses minus normal discretionary expenses, where } \\
\text { discretionary expenses are the sum of research and development, } \\
\text { advertising, and selling, general, and administrative expenses and normal } \\
\text { discretionary expenses is the fitted value from equation (2). }\end{array}$ \\
\hline A_PROD & $\begin{array}{l}\text { Actual production costs minus normal production costs, where productions } \\
\text { costs are the sum of cost of goods sold and the change in inventory and } \\
\text { normal production costs is the fitted value from equation (6). }\end{array}$ \\
\hline ASSETS & Total assets (annual Compustat data item 6). \\
\hline $\mathrm{CFO}$ & $\begin{array}{l}\text { Operating cash flows (annual Compustat data item } 308 \text { - annual Compustat } \\
\text { data item 124) scaled by beginning ASSETS. }\end{array}$ \\
\hline COGS & Cost of goods sold (annual Compustat data item 41). \\
\hline RET & Fama-French three-factor cumulative abnormal returns. \\
\hline DA & $\Delta \mathrm{WC}$ minus NA scaled by beginning ASSETS. \\
\hline DISCX & $\begin{array}{l}\text { Sum of advertising expenses (annual Compustat data item } 45), R \& D \\
\text { expenses (annual Compustat data item 46), and SG\&A (annual Compustat } \\
\text { data item 189). }\end{array}$ \\
\hline IND_ROA & $\begin{array}{l}\text { Industry mean ROA using the Fama-French } 48 \text { industry classification } \\
\text { codes. }\end{array}$ \\
\hline MTB & $\begin{array}{l}\text { Market capitalization divided by book value of common equity (annual } \\
\text { Compustat data item 60), where market capitalization is the price per share } \\
\text { (annual Compustat data item 199) times the number of shares (annual } \\
\text { Compustat data item 25) }\end{array}$ \\
\hline
\end{tabular}




\begin{tabular}{|c|c|}
\hline NA & Nondiscretionary accruals; the fitted value from equation (6). \\
\hline PPE & $\begin{array}{l}\text { Gross value of property, plant, and equipment (annual Compustat data item } \\
\text { 7). }\end{array}$ \\
\hline PROD & Sum of cost of goods sold and the change in inventory. \\
\hline REM & A_CFO, A_PROD, or A_DISCX. \\
\hline REV & Revenue (annual Compustat data item 12) \\
\hline ROA & $\begin{array}{l}\text { Earnings before extraordinary items and discontinued operations (annual } \\
\text { Compustat data item 123)/ASSETS. }\end{array}$ \\
\hline SG & Change in sales scaled by beginning ASSETS. \\
\hline SIZE & Natural logarithm of ASSETS. \\
\hline SOX & $\begin{array}{l}\text { Indicator variable equal to } 1 \text { for post-SOX observations (1990-1998); } 0 \text { for } \\
\text { pre-SOX observations (2003-2012). }\end{array}$ \\
\hline TA & $\begin{array}{l}\text { EXBI - CFO, where EXBI is the earnings before extraordinary items and } \\
\text { discontinued operations (annual Compustat data item 123) and CFO is the } \\
\text { operating cash flows (annual Compustat data item } 308 \text { - annual Compustat } \\
\text { data item 124) scaled by beginning ASSETS. }\end{array}$ \\
\hline Tobin's Q & $\begin{array}{l}\text { (Market value of equity + long-term debt)/(book value of equity + long- } \\
\text { term debt) }\end{array}$ \\
\hline ZSCORE & Altman's (1968) Z-score. \\
\hline
\end{tabular}




\section{References}

Ahmed, A., Lobo, G., and J. Zhou, J. (2011). Job security and income smoothing: An empirical test of the Fudenberg and Tirole (1995) model. Working paper, Texas A\&M University, University of Houston, and University of Hawaii at Manoa.

Alissa, W., Bonsall, S., Koharki, K., \& Penn, M. (2013). Firms' use of accounting discretion to influence their credit ratings. Journal of Accounting and Economics 55: 129-147.

Allen, E., Larson, C., \& Sloan, R. (2013). Accrual reversals, earnings, and stock prices. European Economic Review 62:113-29.

Altman, E. 1968. Financial ratios, discriminant analysis and the prediction of corporate bankruptcy. The Journal of Finance. 23 (4): 589-609.

Ashbaugh-Skaife, H., Collins, D., Kinney, Jr., W., \& Lafond, R. (2009). The Effect of SOX Internal Control Deficiencies on Firm risk and Cost of Equity. Journal of Accounting Research 47: 1-43.

Baber W., Fairfield, P., \& Haggard, J. (1991). The effect of concern about reported income on discretionary spending decisions: The case of research and development. The Accounting Revew 66: 818-829.

Bargeron, L., Lehn, K., \& Zutter, C. (2010). Sarbanes-Oxley and corporate risk taking. Journal of Account and Economics 49: 34-52.

Bartov, E. (1993). The timing of assets sales and earnings manipulation. The Accounting Review 68(4): 840-855.

Bartov, E., \& Cohen, D. (2009). The "numbers game" in the pre- and post-Sarbanes-Oxley eras. Journal of Accounting, Auditing, and Finance 24 (4): 505-534.

Bergstresser, D., \& Philippon, T. (2006). CEO incentives and earnings management. Journal of Financial Economics 80: 511-529.

Bowen, R., Burgstahler, D., \& Daley, L. (1987). The incremental information content of accrual versus cash flows, The Accounting Review 62: 723-747.

Brainard, W. \& Tobin, J. (1968). Pitfalls in financial model-building. American Economic Review 58: 99-122.

Brochet, F. (2010). Information Content of Insider Trades before and after the Sarbanes-Oxley Act. The Accounting Review 85 (2): 419-446.

Burnett, B., Cripe, B., \& Martin, G. (2012). Audit quality and the trade-off between 
accretive stock repurchases and accrual earnings management. The Accounting Review 87: 1861-1884.

Burns, N., \& Kedia, S. (2006). The impact of performance-based compensation on misreporting. Journal of Financial Economics 79: 35-67.

Bushee, B. (1998). The influence of institutional investors on myopic R\&D investment behavior. The Accounting Review 73(3): 305-333.

Carhart, M. (1997). On persistence in mutual fund performance. The Journal of Finance 52:5782.

Chi, W., Lisic, L, \& Pevzner, M. (2011). Is enhanced audit quality associated with greater real earnings management? Accounting Horizons 25 (2): 315-335.

Cohen, D., Dey, A., \& Lys, T. (2008). Real and accrual based earnings management in the pre and post Sarbanes-Oxley periods. The Accounting Review 83: 757-787.

Cohen, D., Mashruwala, R., \& Zach, T. (2010). The use of advertising activities to meet earnings benchmarks: evidence from monthly data. Review of Accounting Studies 15: 808-832.

Cohen, D., \& Zarowin, P. (2010). Accrual and real earnings management activities around seasoned equity offerings. Journal of Accounting and Economics 50: 2-19.

Dechow, P. 1994. Accounting earnings and cash flows as measures of firm performance: The role of accounting accruals. Journal of Accounting and Economics 18 (1): 3-42.

Dechow, P., and Dichev, I. (2002). The quality of accruals and earnings: the role of accrual estimation errors. The Accounting Review 77: 35-59.

Dechow, P., Ge, W., \& Schrand, C. (2010). Understanding earnings quality: a review of the proxies, their determinants and their consequences. Journal of Accounting and Economics 50: 344-401.

Dechow, P., Hutton, A., Kim, J., \& Sloan, R. (2012). Detecting earnings management: A new approach. Journal of Accounting Research 50: 275-334

Dechow, P., Kothari, S., \& Watts, R. (1998). The relation between earnings and cash flows. Journal of Accounting and Economics 25: 133-168.

Dechow, P., Sloan, R., \& Sweeney, A. (1995). Detecting earnings management. The Accounting Review 70: 193-225.

Dechow, P. \& Sloan, R. (1991). Executive incentives and the horizon problem: an empirical investigation. Journal of Accounting and Economics 14: 51-89. 
DeFond, M., \& Park, C. (1997). Smoothing income in anticipation of future earnings. Journal of Accounting and Economics 23: 115-139.

Efendi, J., Srivastava, A., \& Swanson, E. (2007). Why do corporate managers misstate financial statements? The role of option compensation and other factors. Journal of Financial Economics 85: 667-708.

Ewert, R., \&Wagenhofer, A. (2005). Economic effects of tightening accounting standards to restrict earnings management. The Accounting Review 80: 1101-1124.

Fama, E., \&French, K. (1993). Common risk factors in the returns on stocks and bonds, Journal of Financial Economics 33: 3-56.

Fama, E., \& French, K. (1997). Industry costs of equity, Journal of Financial Economics 43: 153-193.

Gavious, I., \& Rosemboim., M. (2013). The disciplining role of the market versus government regulation: The case of Sarbanes-Oxley and the earnings quality of M\&A targets, American Law and Economics Review 15(1): 300-332

Gilliam, T., Heflin, F., \& Paterson, J. (2014). Evidence that the zero-earnings discontinuity has disappeared. Journal of Accounting \& Economics, Forthcoming.

Graham, J., Harvey, C., \& Rajgopal, S. (2005). The economic implications ofcorporate financial reporting. Journal of Accounting and Economics 40: 3-73.

Green, J., Heflin, F., \& Moon, J. (2015). The relevant contributions of value relevance and mispricing of the pricing of abnormal accruals. Working paper, Florida State University and Penn State University.

Gunny, K. (2010). The relation between earnings management using real activities manipulation and future performance: Evidence from meeting earnings benchmarks. Contemporary Accounting Research 27 (3): 855-888.

Healy, P. (1985). The Effect of Bonus Schemes on Accounting Decisions. Journal of Accounting and Economics 7: 85-107.

Healy, P. \& Wahlen, J. (1999). A review of the earnings management literature and its implications for standard setting. Accounting Horizons 13 (October): 365-383.

Jain, P., Kim, J., and Rezaee. Z. (2008). The Sarbanes-Oxley Act of 2002 and Market Liquidity. The Financial Review 43: 361-382.

Jayaraman, S. (2008). Earnings volatility, cash flow, and informed trading. Journal of Accounting Research 46: 809-851 
Jiambalvo, J., Noreen, E., \& Shevlin, T. (1997). Incremental information content of the change in percent of production added to inventory. Contemporary Accounting Research 14: 6997.

Jones, J. (1991). Earnings management during import relief investigations. Journal of Accounting Research 29: 193-228.

Koh, K., Matsumoto, D., \& Rajgopal, S. (2008). Meeting or beating analyst expectations in the post-scandals world: changes in stock market rewards and managerial actions. Contemporary Accounting Research 25: 1067-1098

Kothari, S. and Sloan, R. (1992). Information in prices about future earnings: Implications for earnings response coefficients. Journal of Accounting and Economics 15 (2): 143-172.

Linck, J., Netter, J., \& Shu, T. (2013). Can managers use discretionary accruals to ease financial constraints? Evidence from discretionary accruals prior to investment. The Accounting Review 88: 2117-2143.

Lobo, G., \& Zhou, J. (2006). Did conservatism in financial reporting increase after the SarbanesOxley act? Initial evidence. Accounting Horizons 20(1): 57-73.

Lobo, G., \& Zhou, J. (2010). Changes in discretionary financial reporting behavior following the Sarbanes-Oxley Act. Journal of Accounting, Auditing and Finance 25: 1-26.

Louis, H. (2004). Earnings Management and the market performance of acquiring firms. Journal of Financial Economics 74: 121-148.

Louis, H., \& Robinson, D. (2005). Do managers credibly use accruals to signal private information? Evidence from the pricing of discretionary accruals around stock splits. Journal of Accounting and Economics 39: 361-380.

McAnally, M., Srivastava, A., \& Weaver, C. (2008). Executive stock options, missed earnings targets, earnings management. The Accounting Review 83: 185-216.

McNichols, M. (2002). The Quality of Accruals and Earnings: The Role of Accrual Estimation Errors: Discussion. The Accounting Review 77: 61-69

Mergenthaler, R., Rajgopal, S., \& Srinivasan, S. (2009). CEO and CFO career penalties to missing quarterly analysts' forecasts. Working paper, University of Iowa, Emory University, and Harvard Business School.

Oyer, P. (1998). Fiscal Year Ends and Nonlinear Incentive Contracts: The Effect on Business Seasonality. The Quarterly Journal of Economics 113: 149-185. 
Petroni, K. (1992). Optimistic reporting in the property-casualty insurance industry. Journal of Accounting and Economics 15 (December): 485-508.

Roychowdhury, S. (2006). Earnings management through real activities manipulation. Journal of Accounting and Economics 42: 335-370.

Schipper, K. (1989). Earnings management. Accounting Horizons 3 (1): 91-102.

Sloan, R. (1996). Do stock prices fully reflect information in accruals and cash flows about future earnings? The Accounting Review 71: 289-315.

Subramanyam, K. (1996). The pricing of discretionary accruals. Journal of Accounting and Economics 22 (1-3): 249-281.

Teoh, S., Welch, I., \& Wong, T. (1998). Earnings management and the long-run market performance of initial public offerings. The Journal of Finance 53: 1935-1974.

Thomas, J., \& Zhang, H. (2002). Inventory changes and future returns, Review of Accounting Studies 7: 163-187.

Tucker, J., \& Zarowin, P. (2006). Does income smoothing improve earnings informativeness? The Accounting Review 81: 251-270.

Wilson, G. (1986). The relative information content of accruals and cash flows: combined evidence at the earnings announcement and annual report release date. Journal of Accounting Research 24: 165-200.

Xie, H. (2001). The mispricing of abnormal accruals. The Accounting Review 76 (3): 357-373.

Zang, A. (2012). Evidence on the tradeoff between real manipulation and accrual manipulation. The Accounting Review 87 (2): 675-703.

Zhou, J. (2008). Financial reporting after the Sarbanes-Oxley Act: Conservative or less earnings management? Research in Accounting Regulation 20: 187-192. 
Table 1

Sample Characteristics

Panel A - Descriptive Statistics for Select Variables

\begin{tabular}{|c|c|c|c|c|}
\hline & MEAN & MEDIAN & Q1 & Q3 \\
\hline ASSETS & 3457.44 & 208.78 & 48.02 & 1078.00 \\
\hline $\mathrm{DA}$ & 0.01 & 0.02 & -0.03 & 0.08 \\
\hline A_CFO & 0.01 & 0.01 & -0.07 & 0.18 \\
\hline A_PROD & 0.00 & 0.01 & -0.03 & 0.18 \\
\hline A_DISCX & -0.03 & -0.09 & -0.22 & 0.04 \\
\hline NA & -0.08 & -0.07 & -0.11 & -0.04 \\
\hline $\mathrm{CFO}$ & 0.04 & 0.08 & -0.01 & 0.14 \\
\hline PROD & 0.74 & 0.60 & 0.29 & 1.02 \\
\hline DISCX & 0.36 & 0.28 & 0.12 & 0.49 \\
\hline MTB & 3.31 & 1.99 & 1.19 & 3.47 \\
\hline SIZE & 5.51 & 5.34 & 3.87 & 6.98 \\
\hline SG & 0.05 & 0.00 & -0.00 & 0.00 \\
\hline $\operatorname{RET}_{t, t+3}$ & 0.02 & 0.01 & -0.03 & 0.04 \\
\hline $\mathrm{ROA}_{t+1, t+3}$ & -0.04 & -0.02 & -0.12 & 0.21 \\
\hline TA & -0.07 & -0.05 & -0.10 & -0.01 \\
\hline $\mathrm{N}$ & 45,437 & & & \\
\hline
\end{tabular}




\section{$\begin{array}{lllllllll}\text { DA } & \text { A_CFO } & \text { A_PROD } & \text { A_DISCX } & \text { TA } & \text { NA } & \text { PROD } & \text { CFO } & \text { DISCX }\end{array}$}

\begin{tabular}{|c|c|c|c|c|c|c|c|c|c|}
\hline DA & 1 & & & & & & & & \\
\hline A_CFO & 0.05 & 1 & & & & & & & \\
\hline A_PROD & 0.01 & 0.05 & 1 & & & & & & \\
\hline A_DISCX & 0.16 & 0.28 & 0.02 & 1 & & & & & \\
\hline TA & 0.94 & -0.00 & -0.01 & -0.15 & 1 & & & & \\
\hline NA & -0.10 & 0.16 & 0.01 & -0.20 & 0.21 & 1 & & & \\
\hline PROD & -0.01 & -0.01 & 0.70 & 0.02 & 0.00 & 0.02 & 1 & & \\
\hline CFO & 0.05 & 0.62 & 0.00 & -0.37 & 0.00 & 0.27 & 0.00 & 1 & \\
\hline DISCX & -0.12 & -0.01 & 0.02 & 0.74 & -0.19 & -0.23 & 0.02 & -0.63 & 1 \\
\hline RET $_{t, t+3}$ & 0.03 & 0.08 & 0.02 & -0.02 & -0.04 & -0.04 & 0.00 & 0.03 & 0.07 \\
\hline $\operatorname{ROA}_{t+1, t+3}$ & 0.03 & 0.19 & 0.02 & -0.07 & 0.02 & 0.02 & 0.01 & 0.56 & 0.50 \\
\hline
\end{tabular}

Panel A presents descriptive statistics, and panel B presents a Pearson correlation matrix for our sample of 45,437 firm-year observations for the period $1990-2012$, omitting 2002. All continuous variables are winsorized at the $1^{\text {st }}$ and $99^{\text {th }}$ percentiles. In panel B, numbers reported in bold indicate statistical significance at the $\mathrm{p}<0.05$ level. See Appendix A for detailed descriptions of all variables. 
Table 2

Real Earnings Management Activities and Future Firm Performance

Panel A - Abnormal Cash Flows

$\mathrm{ROA}_{i, t+j}=\alpha+\beta_{1} \mathrm{~A}_{-} \mathrm{CFO}_{i t}+\beta_{2} \mathrm{TA}_{i t}+\beta_{3} \mathrm{CFO}_{i t}+\beta_{4} \mathrm{SG}_{i t}+\beta_{5} \mathrm{SIZE}_{i t}+\beta_{6} \mathrm{MTB}_{i t}+\beta_{7} \mathrm{IND}_{2} \mathrm{ROA}_{i t}+$

$\beta_{8} \mathrm{RET}_{i t+j}+\beta_{9} \mathrm{SOX}_{i t}+\beta_{10} \mathrm{~A}_{-} \mathrm{CFO}_{i t} * \mathrm{SOX}_{i t}+\beta_{k}$ Controls $_{i t} * \operatorname{SOX}_{i t}+\varepsilon$

\begin{tabular}{|c|c|c|c|c|}
\hline $\begin{array}{l}\text { Dependent } \\
\text { Variable }\end{array}$ & $\mathbf{R O A}_{t+1, t+3}$ & $\mathbf{R O A}_{t+1}$ & $\mathbf{R O A}_{t+2}$ & $\mathbf{R O A}_{t+3}$ \\
\hline A_CFO & $0.067 * *$ & $0.023 * * *$ & $0.031 * * *$ & $0.026^{*}$ \\
\hline $\mathrm{T} \overline{\mathrm{A}}$ & $0.918 * * *$ & $0.015 * * *$ & $0.281 * * *$ & $0.255^{* * *}$ \\
\hline $\mathrm{CFO}$ & $2.131 * * *$ & $0.817 * * *$ & $0.707 * * *$ & $0.578 * * *$ \\
\hline SIZE & $0.031 * * *$ & $0.007 * * *$ & $0.018 * * *$ & $0.012 * * *$ \\
\hline IND_ROA & $0.609 * * *$ & $0.170 * * *$ & $0.184 * * *$ & $0.252 * * *$ \\
\hline RETURN & $0.030 * * *$ & $0.032 * * *$ & $0.005 * *$ & $-0.010 * * *$ \\
\hline MTB & $-0.002 * *$ & -0.0001 & $-0.0001 *$ & -0.000 \\
\hline SG & $-0.271^{*}$ & $-0.168 *$ & -0.080 & -0.077 \\
\hline SOX & -0.005 & $-0.016 * * *$ & $-0.009 * * *$ & $0.022 * * *$ \\
\hline A_CFO*SOX (-) & $-0.074 * * *$ & $-0.027 * * *$ & $-0.032 * * *$ & $-0.034 * * *$ \\
\hline INTERCEPT & $-0.275 * * *$ & $-0.048 * * *$ & $-0.036 * * *$ & $-0.121 * * *$ \\
\hline
\end{tabular}


Panel B - Abnormal Production Costs

$\mathrm{ROA}_{i, t+j}=\alpha+\beta_{1} \mathrm{~A}_{-} \mathrm{PROD}_{i t}+\beta_{2} \mathrm{TA}_{i t}+\beta_{3} \mathrm{CFO}_{i t}+\beta_{4} \mathrm{SG}_{i t}+\beta_{5} \mathrm{SIZE}_{i t}+\beta_{6} \mathrm{MTB}_{i t}+\beta_{7} \mathrm{IND}_{-} \mathrm{ROA}_{i t}+$

$\beta_{8} \mathrm{RET}_{i t+j}+\beta_{9} \mathrm{SOX}_{i t}+\beta_{10} \mathrm{~A}_{-} \mathrm{PROD}_{i t} * \mathrm{SOX}_{i t}+\beta_{k}$ Controls $_{i t} * \operatorname{SOX}_{i t}+\varepsilon$

\begin{tabular}{|c|c|c|c|c|}
\hline $\begin{array}{l}\text { Dependent } \\
\text { Variable }\end{array}$ & $\mathbf{R O A}_{t+1, t+3}$ & $\mathbf{R O A}_{t+1}$ & $\mathbf{R O A}_{t+2}$ & $\mathbf{R O A}_{t+3}$ \\
\hline A_PROD & $0.140 * * *$ & $0.045 * * *$ & $0.053 * * *$ & $0.032 * *$ \\
\hline $\mathrm{TA}$ & $0.916 * * *$ & $0.375 * * *$ & $0.280 * * *$ & $0.255^{* * *}$ \\
\hline $\mathrm{CFO}$ & $2.107 * * *$ & $0.804 * * *$ & $0.686 * * *$ & $0.581 * * *$ \\
\hline SIZE & $0.033 * * *$ & $0.008 * * *$ & $0.012 * * *$ & $0.012 * * *$ \\
\hline IND_ROA & $0.623 * * *$ & $0.180 * * *$ & $0.202 * * *$ & $0.244 * * *$ \\
\hline RETURN & $0.026 * * *$ & $0.032 * * *$ & $0.005 * *$ & $-0.010 * * *$ \\
\hline МТB & $-0.003^{* *}$ & -0.000 & $-0.001 *$ & -0.000 \\
\hline SG & $-0.291 *$ & $-0.174 * *$ & -0.089 & -0.082 \\
\hline SOX & 0.007 & $-0.026 * * *$ & -0.003 & $0.025 * * *$ \\
\hline A_PROD*SOX (-) & $-0.070 * *$ & $-0.019 * *$ & $-0.023^{*}$ & -0.019 \\
\hline INTERCEPT & $-0.297 * * *$ & $-0.055 * * *$ & $-0.036 * * *$ & $-0.126 * * *$ \\
\hline
\end{tabular}


Panel C - Abnormal Discretionary Expenses

$\mathrm{ROA}_{i, t+j}=\alpha+\beta_{1} \mathrm{~A}_{-} \mathrm{DISCX}_{i t}+\beta_{2} \mathrm{TA}_{i t}+\beta_{3} \mathrm{CFO}_{i t}+\beta_{4} \mathrm{SG}_{i t}+\beta_{5} \mathrm{SIZE}_{i t}+\beta_{6} \mathrm{MTB}_{i t}+\beta_{7} \mathrm{IND}_{-} \mathrm{ROA}_{i t}$

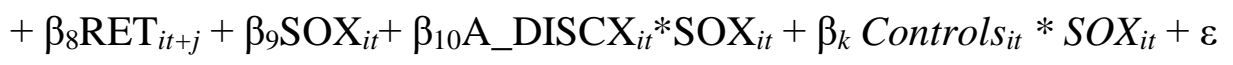

\begin{tabular}{|c|c|c|c|c|}
\hline Dependent Variable & $\operatorname{ROA}_{t+1, t+3}$ & $\mathbf{R O A}_{t+1}$ & $\mathbf{R O A}_{t+2}$ & $\mathbf{R O A}_{t+3}$ \\
\hline A_DISCX & $0.039 * *$ & $0.189 * * *$ & $-0.010^{*}$ & $-0.017 * *$ \\
\hline $\mathrm{TA}$ & $0.943 * * *$ & $0.383 * * *$ & $0.289 * * *$ & $0.268 * * *$ \\
\hline $\mathrm{CFO}$ & $2.132 * * *$ & $0.812 * * *$ & $0.695 * * *$ & $0.593 * * *$ \\
\hline SIZE & $0.033 * * *$ & $0.008 * * *$ & $0.012 * * *$ & $0.013 * * *$ \\
\hline IND_ROA & $0.567 * * *$ & $0.180 * * *$ & $0.183 * * *$ & $0.215 * * *$ \\
\hline RETURN & $0.028 * * *$ & $0.032 * * *$ & $0.006 * *$ & $-0.010 * * *$ \\
\hline MTB & $-0.003 * * *$ & -0.000 & $-0.001 * *$ & -0.001 \\
\hline SG & $-0.283^{*}$ & $-0.170 * *$ & -0.086 & -0.084 \\
\hline SOX & 0.006 & $-0.027 * * *$ & -0.003 & $0.025 * * *$ \\
\hline A_DISCX*SOX (-) & $-0.022 *$ & $-0.016^{* *}$ & -0.003 & -0.007 \\
\hline INTERCEPT & $-0.292 * * *$ & $-0.053 * * *$ & $-0.092 * * *$ & $-0.127 * * *$ \\
\hline
\end{tabular}

$* * *, * *$, and $*$ indicate statistical significance at the $0.01,0.05$, and 0.10 levels, respectively, using a 1 -tailed test. Tstatistics are in parentheses. Standard errors are clustered by firm. Year and industry indicator variables as well as SOX interactions with other control variables are omitted for brevity. All continuous variables are winsorized at the $1^{\text {st }}$ and $99^{\text {th }}$ percentiles. Panels A, B, and C present the results of estimating equation (7) with return on assets as the dependent variable and $A_{-} C F O, A \_D I S C X$, and $A_{-} P R O D$ as the respective variables of interest. The columns $\mathrm{ROA}_{t+1, t+3}, \mathrm{ROA}_{t+1}, \mathrm{ROA}_{\mathrm{t}+2}$, and $\mathrm{ROA}_{\mathrm{t}+3}$ represent the ROA for periods $\mathrm{t}+1$ through $\mathrm{t}+3, \mathrm{t}+1, \mathrm{t}+2$, and $\mathrm{t}+3$, respectively. See Appendix A for detailed descriptions of all variables. 
Table 3

Market Pricing of Real Earnings Management Activities

Panel A - Abnormal Cash Flows

$\mathrm{RET}_{i, t+j}=\alpha+\beta_{1} \mathrm{~A}_{-} \mathrm{CFO}_{i t}+\beta_{2} \mathrm{TA}_{i t}+\beta_{3} \mathrm{CFO}_{i t}+\beta_{4} \mathrm{SG}_{i t}+\beta_{5} \mathrm{SIZE}_{i t}+\beta_{6} \mathrm{MTB}_{i t}+\beta_{7} \mathrm{SOX}_{i t}+$ $\beta_{8} \mathrm{~A} \_C F O_{i t} * \mathrm{SOX}_{i t}+\beta_{k}$ Controls $_{i t} * S O X_{i t}+\varepsilon_{i t}$

\begin{tabular}{|c|c|c|c|c|c|}
\hline $\begin{array}{l}\text { Dependent } \\
\text { Variable }\end{array}$ & $R E T_{t, t+3}$ & $\mathbf{R E T}_{t}$ & $\mathbf{R E T}_{t+1}$ & $\mathbf{R E T}_{t+2}$ & $R E T_{t+3}$ \\
\hline A_CFO & $0.188 * * *$ & $0.211 * * *$ & $0.205 * * *$ & $-0.121 * * *$ & $-0.043^{*}$ \\
\hline $\mathrm{CF} \mathrm{FO}$ & $2.147 * * *$ & $0.897 * * *$ & $0.201 * * *$ & $0.124 * * *$ & $0.136 * * *$ \\
\hline $\mathrm{TA}$ & $0.515 * * *$ & $0.297 * * *$ & $0.057 * *$ & $0.097 * *$ & 0.047 \\
\hline SIZE & $-0.032 * * *$ & $-0.022 * * *$ & $-0.016 * * *$ & $-0.011 * * *$ & $-0.003 * *$ \\
\hline SG & 0.391 & $0.938 * * *$ & $-0.325 * *$ & -0.231 & -0.003 \\
\hline MTB & 0.001 & $0.017 * * *$ & $-0.009 * * *$ & $-0.004 * * *$ & $-0.002 * * *$ \\
\hline SOX & 0.047 & $0.315 * * *$ & $-0.316 * * *$ & $0.191 * * *$ & $-0.077 * * *$ \\
\hline A_CFO*SOX (-) & $-0.256 * * *$ & $-0.181 * * *$ & $-0.164 * * *$ & $-0.060 * *$ & $-0.053 * *$ \\
\hline INTERCEPT & $-0.724 * * *$ & $-0.056 * * *$ & $-0.542 * * *$ & $-0.054 * * *$ & $0.150 * * *$ \\
\hline
\end{tabular}


Panel B - Abnormal Production Costs

$\mathrm{RET}_{i, t+j}=\alpha+\beta_{1} \mathrm{~A}_{-} \mathrm{CFO}_{i t}+\beta_{2} \mathrm{TA}_{i t}+\beta_{3} \mathrm{CFO}_{i t}+\beta_{4} \mathrm{SG}_{i t}+\beta_{5} \mathrm{SIZE}_{i t}+\beta_{6} \mathrm{MTB}_{i t}+\beta_{7} \mathrm{SOX}_{i t}+$

$\beta_{8} \mathrm{~A}_{-} \mathrm{CFO}_{i t} * \mathrm{SOX}_{i t}+\beta_{k}$ Controls $_{i t} * \operatorname{SOX}_{i t}+\varepsilon_{i t}$

\begin{tabular}{|c|c|c|c|c|c|}
\hline $\begin{array}{l}\text { Dependent } \\
\text { Variable }\end{array}$ & $R E T_{t, t+3}$ & $\mathbf{R E T}_{t}$ & $\mathbf{R E T}_{t+1}$ & $\mathbf{R E T}_{t+2}$ & $R E T_{t+3}$ \\
\hline A_PROD & $0.106^{*}$ & $0.038 * *$ & $0.103^{* *}$ & $-0.121 * * *$ & $-0.043^{*}$ \\
\hline CFO & $1.035 * * *$ & $0.295 * * *$ & $0.205 * * *$ & $0.124 * * *$ & $0.189 * * *$ \\
\hline TA & $0.526 * * *$ & $0.251 * * *$ & $0.240 * * *$ & $0.097 * *$ & $0.132 * *$ \\
\hline SIZE & $-0.041 * * *$ & $-0.020 * * *$ & $-0.011 * * *$ & $-0.011 * * *$ & $-0.003 * *$ \\
\hline SG & 0.395 & $0.918 * * *$ & $-0.356^{*}$ & -0.206 & 0.035 \\
\hline MTB & $0.002 * * *$ & $0.018 * * *$ & $-0.004 * * *$ & $-0.004 * * *$ & $-0.002 * * *$ \\
\hline SOX & $0.072 * * *$ & $0.314^{* * *} *$ & $-0.274 * * *$ & $0.167 * * *$ & $-0.088 * * *$ \\
\hline A_PROD*SOX (-) & $-0.222 * * *$ & -0.015 & $-0.038^{*}$ & $-0.212 * * *$ & $-0.123 * * *$ \\
\hline INTERCEPT & $0.733 * * *$ & $-0.072 * * *$ & $0.480 * * *$ & -0.003 & $0.204 * * *$ \\
\hline
\end{tabular}


Panel C - Abnormal Discretionary Expenses

$\mathrm{RET}_{i, t+j}=\alpha+\beta_{1} \mathrm{~A}_{-} \mathrm{DISCX}_{i t}+\beta_{2} \mathrm{TA}_{i t}+\beta_{3} \mathrm{CFO}_{i t}+\beta_{4} \mathrm{SG}_{i t}+\beta_{5} \mathrm{SIZE}_{i t}+\beta_{6} \mathrm{MTB}_{i t}+\beta_{7} \mathrm{SOX}_{i t}+$

$\beta_{8} \mathrm{~A} \_\mathrm{DISCX}_{i t}{ }^{*} \mathrm{SOX}_{i t}+\beta_{k}$ Controls $_{i t} * \operatorname{SOX}_{i t}+\varepsilon_{i t}$

\begin{tabular}{|c|c|c|c|c|c|}
\hline $\begin{array}{l}\text { Dependent } \\
\text { Variable }\end{array}$ & $R E T_{t, t+3}$ & $\mathbf{R E T}_{t}$ & $\mathbf{R E T}_{t+1}$ & $\mathbf{R E T}_{t+2}$ & $R E T_{t+3}$ \\
\hline A_DISCX & $0.160 * * *$ & $0.032 * *$ & $-0.136 * * *$ & $-0.039 * *$ & -0.004 \\
\hline $\mathrm{CF} \mathrm{F}$ & $1.655^{* * *}$ & $0.304 * * *$ & $0.234 * * *$ & $0.098 * * *$ & $0.139 * * *$ \\
\hline $\mathrm{TA}$ & $0.488 * * *$ & $0.263 * * *$ & $0.057 * *$ & $0.065 * *$ & $0.085 * * *$ \\
\hline SIZE & $-0.038 * * *$ & $-0.022 * * *$ & $-0.014 * * *$ & $-0.007 * * *$ & -0.002 \\
\hline SG & 0.386 & $0.938 * * *$ & $-0.322 *$ & -0.232 & -0.008 \\
\hline MTB & $0.002 * *$ & $0.017 * * *$ & $-0.009 * * *$ & $-0.004 * * *$ & $-0.002 * *$ \\
\hline SOX & $0.055 * *$ & $0.317 * * *$ & $-0.280 * * *$ & $0.191 * * *$ & $-0.077 * * *$ \\
\hline A_DISCX*SOX (-) & $-0.163 * * *$ & $-0.032 * * *$ & $-0.156^{* * *}$ & $-0.050 * * *$ & -0.004 \\
\hline INTERCEPT & $-0.728 * * *$ & $-0.060 * * *$ & $0.502 * * *$ & $-0.021 * *$ & $0.178 * * *$ \\
\hline
\end{tabular}

$* * *, * *$, and * indicate statistical significance at the $0.01,0.05$, and 0.10 levels, respectively, using a 1 -tailed test. Tstatistics are in parentheses. Standard errors are clustered by firm. Year and industry indicator variables as well as SOX interactions with other control variables are omitted for brevity. All continuous variables are winsorized at the $1^{\text {st }}$ and $99^{\text {th }}$ percentiles. Panels A, B, and C present the results of estimating equation (8) with buy-and-hold stock returns as the dependent variable and $A_{-} C F O, A_{-} D I S C X$, and $A_{-} P R O D$ as the respective variables of interest. The columns $R E T_{t, t+3}, R E T_{t}, R E T_{t+1}, R E T_{t+2}$, and $R E T_{t+3}$ represent returns for periods through $\mathrm{t}+3, \mathrm{t}, \mathrm{t}+1, \mathrm{t}+2$, and $\mathrm{t}+3$, respectively. See Appendix A for detailed descriptions of all variables. 


\section{Table 4}

\section{Discretionary Accruals and Future Firm Performance}

$\mathrm{ROA}_{i, t+j}=\alpha+\beta_{1} \mathrm{DA}_{i t}+\beta_{2} \mathrm{TA}_{i t}+\beta_{3} \mathrm{CFO}_{i t}+\beta_{4} \mathrm{SG}_{i t}+\beta_{5} \mathrm{SIZE}_{i t}+\beta_{6} \mathrm{MTB}_{i t}+\beta_{7} \mathrm{IND}_{-} \mathrm{ROA}_{i t}+$

$\beta_{8} \mathrm{RET}_{i t+j}+\beta_{9} \mathrm{SOX}_{i t}+\beta_{10} \mathrm{DA}_{i t} * \mathrm{SOX}_{i t}+\beta_{k}$ Controls $_{i t} * \operatorname{SOX}_{i t}+\varepsilon$

\begin{tabular}{|c|c|c|c|c|}
\hline Dependent Variable & $\operatorname{ROA}_{t+1, t+3}$ & $\mathbf{R O A}_{t+1}$ & $\mathbf{R O A}_{t+2}$ & $\mathbf{R O A}_{t+3}$ \\
\hline $\mathrm{DA}$ & $-0.051 * * *$ & $-0.035 * * *$ & $-0.018 *$ & -0.001 \\
\hline TA & $1.161 * * *$ & $0.501 * * *$ & $0.329 * * *$ & $0.311 * * *$ \\
\hline $\mathrm{CFO}$ & $2.104 * * *$ & $0.802 * * *$ & $0.686 * * *$ & $0.581 * * *$ \\
\hline SIZE & $0.030 * * *$ & $0.007 * * *$ & $0.011 * * *$ & $0.012 * * *$ \\
\hline IND_ROA & $0.567 * * *$ & $0.162 * * *$ & $0.195 * * *$ & $0.235 * * *$ \\
\hline RETŪRN & $0.025^{* * *}$ & $0.031 * * *$ & $0.005^{* *}$ & $-0.011 * * *$ \\
\hline MTB & $-0.003 * * *$ & -0.000 & $-0.001 * *$ & -0.000 \\
\hline SG & -0.269 & $-0.164 * *$ & -0.080 & -0.080 \\
\hline SOX & 0.006 & $-0.023 * * *$ & -0.002 & $0.028 * * *$ \\
\hline DA*SOX (-) & $0.022 * *$ & $0.010 *$ & 0.007 & $0.016^{*}$ \\
\hline INTERCEPT & $-0.292 * * *$ & $-0.040 * * *$ & $-0.084 * * *$ & $-0.120 * * *$ \\
\hline
\end{tabular}

***, **, and * indicate statistical significance at the $0.01,0.05$, and 0.10 levels, respectively, using a 1 -tailed test. Tstatistics are in parentheses. Standard errors are clustered by firm. Year and industry indicator variables as well as SOX interactions with other control variables are omitted for brevity. All continuous variables are winsorized at the $1^{\text {st }}$ and $99^{\text {th }}$ percentiles. Table 4 presents the results of estimating equation (9) with return on assets as the dependent variable and $D A$ as the variable of interest. The columns $R O A_{t+1, t+3}, R O A_{t+1}, R O A_{t+2}$, and $R O A_{t+3}$ represent the ROA for periods $\mathrm{t}+1$ through $\mathrm{t}+3, \mathrm{t}+1, \mathrm{t}+2$, and $\mathrm{t}+3$, respectively. See Appendix A for detailed descriptions of all variables. 


\section{Table 5}

\section{Market Pricing of Discretionary Accruals}

$$
\begin{aligned}
R E T_{i, t+j}= & \alpha_{1}+\beta_{1} * D A_{i t}+\beta_{2} * T A_{i t}+\beta_{3} * O C F_{i t}+\beta_{4} * S G_{i t}+ \\
& \beta_{5} * S I Z E_{i t}+\beta_{6} * M T B_{i t}+\beta_{7} * S O X_{i t}+\beta_{8} * D A_{i t} * S O X_{i t}+\Sigma \beta_{k} * \\
& \text { Control }_{k} * S_{S O X}+\epsilon_{i, t}
\end{aligned}
$$

\begin{tabular}{|c|c|c|c|c|c|}
\hline $\begin{array}{l}\text { Dependent } \\
\text { Variable }\end{array}$ & $R E T_{t, t+3}$ & $\mathbf{R E T}_{t}$ & $\mathbf{R E T}_{t+1}$ & $\mathbf{R E T}_{t+2}$ & $R E T_{t+3}$ \\
\hline $\mathrm{DA}$ & $0.233 * * *$ & $0.533 * * *$ & $-0.196 * * *$ & -0.018 & $-0.13^{*}$ \\
\hline $\mathrm{CFO}$ & $2.432 * * *$ & $1.528 * * *$ & $1.425 * * *$ & $0.927 * * *$ & $0.388 * * *$ \\
\hline $\mathrm{TA}$ & $1.107 * * *$ & $0.204 * * *$ & $0.182 * * *$ & $0.102 * *$ & 0.022 \\
\hline SIZE & $-0.031 * * *$ & $-0.027 * * *$ & $-0.006^{* * *}$ & $-0.010 * * *$ & -0.000 \\
\hline $\mathrm{SG}$ & 0.344 & $0.962 * * *$ & $-0.380 * *$ & -0.244 & -0.016 \\
\hline MTB & 0.002 & $0.017 * * *$ & $-0.009 * * *$ & $-0.004 * * *$ & $-0.002 * * *$ \\
\hline SOX & 0.027 & $0.349 * * *$ & $-0.311 * * *$ & $0.141 * * *$ & $-0.104 * * *$ \\
\hline DA*SOX (-) & 0.021 & $-0.150 * *$ & $0.165 * *$ & $0.011 *$ & 0.008 \\
\hline INTERCEPT & $-0.543 * * *$ & $0.052 * * *$ & $0.332 * * *$ & $-0.092 * * *$ & $0.131 * * *$ \\
\hline
\end{tabular}

***, **, and * indicate statistical significance at the $0.01,0.05$, and 0.10 levels, respectively, using a 1 -tailed test. Tstatistics are in parentheses. Standard errors are clustered by firm. Year and industry indicator variables as well as SOX interactions with other control variables are omitted for brevity. All continuous variables are winsorized at the $1^{\text {st }}$ and $99^{\text {th }}$ percentiles. Table 5 presents the results of estimating equation (10) with buy-and-hold stock returns as the dependent and $D A$ as the variable of interest. $D A$ is discretionary accruals and is calculated by estimating equation (7). The columns $R E T_{t, t+3}, R E T_{t}, R E T_{t+1}, R E T_{t+2}$, and $R E T_{t+3}$ represent returns for periods $\mathrm{t}$ through $\mathrm{t}+3, \mathrm{t}$, $\mathrm{t}+1, \mathrm{t}+2$, and $\mathrm{t}+3$, respectively. See Appendix A for detailed descriptions of all variables. 
Table 6

Future Return on Assets by Quintile of Accrual and Real Earnings Management

Panel A - Pre-SOX

\begin{tabular}{|c|c|l|l|l|l|}
\hline & Total & DA $^{\text {Low }}$ & DA $^{\text {Med }}$ & DA $^{\text {High }}$ & DA $^{\text {H-L }}$ \\
\hline Total & & $-0.04^{* *}$ & 0.04 & $-0.08^{* * *}$ & $-0.04 * *$ \\
\hline REM $^{\text {Low }}$ & -0.01 & $-0.08^{* * *}(896)$ & $0.05^{* * *}(2,689)$ & $-0.11^{* * *}(896)$ & $-0.03^{* *}$ \\
\hline REM $^{\text {Med }}$ & 0.01 & $-0.02^{*}(2,688)$ & $0.04 * *(8,065)$ & $-0.06^{* * *}(2,689)$ & $-0.04 * *$ \\
\hline REM $^{\text {High }}$ & -0.00 & $-0.07 * * *(896)$ & $0.05^{* * *}(2,689)$ & $-0.09 * * *(896)$ & $-0.02 * *$ \\
\hline REM $^{\boldsymbol{H}-\boldsymbol{L}}$ & 0.01 & 0.01 & 0.00 & -0.01 & \\
\hline
\end{tabular}

Panel B - Post-SOX

\begin{tabular}{|c|c|c|c|c|c|}
\hline & Total & DA $^{\text {Low }}$ & DA $^{\text {Med }}$ & DA $^{\text {High }}$ & DA $^{\text {H-L }}$ \\
\hline Total & & $-0.06 * * *$ & $0.02 * *$ & $-0.03^{* *}$ & $0.03 * *$ \\
\hline REM $^{\text {Low }}$ & $0.02 * *$ & $-0.05^{* * *}(921)$ & $0.03 * * *(2,765)$ & $0.04 * *(921)$ & $0.09 * * *$ \\
\hline REM $^{\text {Med }}$ & 0.01 & $-0.04 * * *(2,765)$ & $0.03 * * *(8,065)$ & $-0.02 *(2,765)$ & $0.02 * *$ \\
\hline REM $^{\text {High }}$ & $-0.07 * * *$ & $-0.11^{* * *}(921)$ & $-0.04 * * *(2,765)$ & $-0.11 * * *(921)$ & 0.00 \\
\hline REM $^{\text {H-L }}$ & $-0.09 * * *$ & $-0.06 * * *$ & $-0.07 * * *$ & $-0.15 * * *$ & \\
\hline
\end{tabular}

Effect of REM, Post-SOX - Pre-SOX:

\begin{tabular}{|c|c|c|c|c|}
\hline & Total & DA $^{\text {Low }}$ & DA $^{\text {Med }}$ & DA $^{\text {High }}$ \\
\hline REM $^{\boldsymbol{H}-\boldsymbol{L}}$ & $-0.10^{* * * *}$ & $-0.07^{* *}$ & $-0.07 * * *$ & $-0.17^{* * *}$ \\
\hline
\end{tabular}

Effect of DA, Post-SOX - Pre-SOX:

\begin{tabular}{|l|c|c|c|l|}
\hline & Total & REM $^{\text {Low }}$ & REM $^{\text {Med }}$ & REM $^{\text {High }}$ \\
\hline $\mathbf{D A}^{\boldsymbol{H}-\boldsymbol{L}}$ & $0.07 * * *$ & $0.12^{* * *}$ & $0.06^{* * *}$ & $0.02^{* *}$ \\
\hline
\end{tabular}

$* * *, * *$, and $*$ indicate statistical significance at the $0.01,0.05$, and 0.10 levels, respectively, using one-tailed tests. The number of observations is in parentheses where applicable. Table 6 presents the mean cumulative future $R O A$ $\left(R O A_{t+1, t+3}\right.$, ) conditional on levels of earnings management pre- and post-SOX. We split firms into quintiles based on yearly real and accrual earnings management ranks. We define observations in the highest (lowest) quintile of each type of earnings management as high (low). We define observations in the middle three quintiles of each type of earnings management as medium. The shaded total column (row) presents $R O A_{t+1, t+3}$, conditional on real earnings management (discretionary accruals). The next three columns (rows) present $R O A_{t+1, t+3}$, conditional on both real earnings management and discretionary accruals. $D A^{H-L}\left(R E M^{H-L}\right)$ is defined as the difference in $R O A_{t+1, t+3}$, for observations in the high quintile of discretionary accruals (real earnings management) and observations in the low quintile of discretionary accruals (real earnings management). Finally, in the Post-SOX - Pre-SOX panels, we compare $R O A_{t+1, t+3}$, differences $\left(D A^{H-L}\right.$ and $\left.R E M^{H-L}\right)$ across the pre- and post-SOX time periods. 
Table 7 Cumulative Abnormal Stock Returns by Quintile of Accrual and Real Earnings
Management

Panel A - Pre-SOX

\begin{tabular}{|c|c|c|c|c|c|}
\hline & Total & DA $^{\text {Low }}$ & DA $^{\text {Med }}$ & DA $^{\text {High }}$ & DA $^{\text {H-L }}$ \\
\hline Total & & $-0.11^{* * *}$ & $0.02^{* *}$ & 0.01 & $0.12 * * *$ \\
\hline REM $^{\text {Low }}$ & $-0.07 * * *$ & $-0.12 * * *(896)$ & $-0.08^{* * *}(2,689)$ & $0.01(896)$ & $0.13 * * *$ \\
\hline REM $^{\text {Med }}$ & 0.00 & $-0.12 * * *(2,688)$ & $0.04 * * *(8,065)$ & $0.01(2,689)$ & $0.13 * * *$ \\
\hline REM $^{\text {igh }}$ & $0.02 * *$ & $-0.09 * * *(896)$ & $0.05 * * *(2,689)$ & $0.03 * *(896)$ & $0.12 * * *$ \\
\hline REM $^{\boldsymbol{H}-\boldsymbol{L}}$ & $0.09 * * *$ & $0.03 * *$ & $0.13 * * *$ & $0.02 *$ & \\
\hline
\end{tabular}

Panel B - Post-SOX

\begin{tabular}{|c|c|c|c|c|c|}
\hline & Total & DA $^{\text {Low }}$ & DA $^{\text {Med }}$ & DA $^{\text {High }}$ & DA $^{\text {H-L }}$ \\
\hline Total & & $-0.12 * * *$ & $0.03 * *$ & $0.04 * *$ & $0.16^{* * *}$ \\
\hline REM $^{\text {Low }}$ & $0.06 * * *$ & $-0.03 * *(921)$ & $0.07 * * *(2,765)$ & $0.14 * * *(921)$ & $0.17 * * *$ \\
\hline REM $^{\text {Med }}$ & $0.03 * *$ & $-0.12 * * *(2,765)$ & $0.07 * * *(8,065)$ & $0.04 * *(2,765)$ & $0.16 * * *$ \\
\hline REM $^{\text {igh }}$ & $-0.12 * * *$ & $-0.20 * * *(921)$ & $-0.11 * * *(2,765)$ & $-0.08 * * *(921)$ & $0.12 * * *$ \\
\hline REM $^{\boldsymbol{H}-\boldsymbol{L}}$ & $-0.18 * * *$ & $-0.17 * * *$ & $-0.18 * * *$ & $-0.22 * * *$ & \\
\hline
\end{tabular}

Effect of REM, Post-SOX - Pre-SOX:

\begin{tabular}{|c|c|c|c|c|}
\hline & Total & DA $^{\text {Low }}$ & DA $^{\text {Med }}$ & DA $^{\text {High }}$ \\
\hline REM $^{H-L}$ & $-0.27^{* * *}$ & $-0.20^{* * *}$ & $-0.31^{* * *}$ & $-0.24^{* * *}$ \\
\hline
\end{tabular}

Effect of DA, Post-SOX - Pre-SOX:

\begin{tabular}{|l|l|l|l|l|}
\hline & Total & REM $^{\text {Low }}$ & REM $^{\text {Med }}$ & REM $^{\text {High }}$ \\
\hline $\mathbf{D A}^{\boldsymbol{H}-\boldsymbol{L}}$ & $0.04^{* *}$ & $0.04^{* *}$ & $0.03^{* *}$ & 0.00 \\
\hline
\end{tabular}

$* * *, * *$, and $*$ indicate statistical significance at the $0.01,0.05$, and 0.10 levels, respectively, using one-tailed tests. The number of observations is in parentheses where applicable. Table 7 presents cumulative stock returns $\left(R E T_{t, t+3}\right.$, ) conditional on levels of earnings management pre- and post-SOX. We split firms into quintiles based on yearly real and accrual earnings management ranks. We define observations in the highest (lowest) quintile of each type of earnings management as high (low). We define observations in the middle three quintiles of each type of earnings management as medium. The shaded total column (row) presents $R E T_{t, t+3}$, conditional on real earnings management (discretionary accruals). The next three columns (rows) present $R E T_{t, t+3}$, conditional on both real earnings management and discretionary accruals. $D A^{H-L}\left(R E M^{H-L}\right)$ is defined as the difference in $R E T_{t, t+3}$, for observations in the high quintile of discretionary accruals (real earnings management) and observations in the low quintile of discretionary accruals (real earnings management). Finally, in the Post-SOX - Pre-SOX panels, we compare $R E T_{t, t+3}$, differences $\left(D A^{H-L}\right.$ and $\left.R E M^{H-L}\right)$ across the pre- and post-SOX time periods. 


\section{Table 8}

\section{Suspect Firms and Future Firm Performance}

\section{Panel A}

\begin{tabular}{|c|c|c|c|c|}
\hline DV & $\mathbf{R O A}_{t+1, t+3}$ & $\operatorname{ROA}_{t+1, t+3}$ & $\operatorname{ROA}_{t+1, t+3}$ & $\operatorname{ROA}_{t+1, t+3}$ \\
\hline$\overline{\mathrm{DA}}$ & $-0.086 * * *$ & & & \\
\hline A_CFO & & $0.091 * * *$ & & \\
\hline A_PROD & & & 0.140 & \\
\hline A_DISCX & & & & $0.039 * *$ \\
\hline $\mathrm{TA}$ & $1.001 * * *$ & $0.770 * * *$ & $0.943 * * *$ & $1.131 * * *$ \\
\hline $\mathrm{CFO}$ & $1.994 * * *$ & $2.714 * * *$ & $2.113 * * *$ & $2.075^{* * *}$ \\
\hline SIZE & $0.030 * * *$ & $0.031 * * *$ & $0.031 * * *$ & $0.031 * * *$ \\
\hline IND_ROA & $0.565 * * *$ & $0.615 * * *$ & $0.667 * * *$ & $0.609 * * *$ \\
\hline RETURN & $0.012 * * *$ & $0.089 * * *$ & $0.044 * * *$ & $0.027 * * *$ \\
\hline MTB & $-0.003 * * *$ & $-0.002 * * *$ & $-0.003 * * *$ & $-0.003 * * *$ \\
\hline SG & -0.201 & $-0.271 *$ & -0.242 & -0.259 \\
\hline SOX & 0.009 & 0.005 & 0.009 & 0.009 \\
\hline $\mathrm{DA} * \mathrm{SOX}(+)$ & $0.039 * * *$ & & & \\
\hline A_CFO*SOX (-) & & $-0.107 * * *$ & & \\
\hline A_PROD*SOX (-) & & & $-0.124 * * *$ & \\
\hline A_DISCX *SOX (-) & & & & $-0.114 * * *$ \\
\hline INTERCEPT & $-0.292 * * *$ & $-0.275 * * *$ & $-0.244 * * *$ & $-0.291 * * *$ \\
\hline
\end{tabular}

Panel B
\begin{tabular}{|l|l|}
\hline Pre-SOX & $-0.03 * *(1,250)$ \\
\hline Post-SOX & $-0.08^{* * *}(933)$ \\
\hline Post-Pre & $-0.05 * * *$ \\
\hline
\end{tabular}

$* * *, * *$, and * indicate statistical significance at the $0.01,0.05$, and 0.10 levels, respectively, using a 1 -tailed test. Tstatistics are in parentheses. Standard errors are clustered by firm. Year and industry indicator variables as well as SOX interactions with other control variables are omitted for brevity. All continuous variables are winsorized at the $1^{\text {st }}$ and $99^{\text {th }}$ percentiles. We identify suspect firm years as years in which a firms earnings scaled by assets in the current year are 0.01 more than earnings scaled by assets from the prior year. Panel A of Table 8 presents the results of estimating equations (7) and (9) with return on assets as the dependent variable and $D A, A \_C F O, A \_P R O D$, and $A \_D I S C X$ as the variables of interest for suspect firm-year observations. The columns $R O A_{t+1, t+3}$, represent the ROA for periods $t+1$ through $t+3$. Panel B of Table 8 presents the three year return on assets in the pre- and post-SOX period for suspect firms. See Appendix A for detailed descriptions of all variables. 
Table 9

Suspect Firms and Market Pricing of Earnings Management

\begin{tabular}{|c|c|c|c|c|}
\hline DV & $R E T_{t, t+3}$ & $R E T_{t, t+3}$ & $R E T_{t, t+3}$ & $R E T_{t, t+3}$ \\
\hline$\overline{\mathrm{DA}}$ & $0.201 * * *$ & & & \\
\hline A_CFO & & $0.160 * * *$ & & \\
\hline A_PROD & & & $0.155^{* *}$ & \\
\hline A_DISCX & & & & $0.161 * * *$ \\
\hline $\mathrm{CFO}$ & $2.433 * * *$ & $2.110 * * *$ & $1.056 * * *$ & $1.641 * * *$ \\
\hline TA & $1.116^{* * *}$ & $0.517 * * *$ & $0.774 * * *$ & $0.589 * * *$ \\
\hline SIZE & $-0.031 * * *$ & $-0.033 * * *$ & $-0.041 * * *$ & $-0.038 * * *$ \\
\hline SG & 0.343 & 0.391 & -0.395 & 0.387 \\
\hline MTB & 0.002 & 0.001 & $0.002 * * *$ & $0.002 * *$ \\
\hline SOX & 0.029 & 0.047 & $0.072 * * *$ & $0.057 * *$ \\
\hline DA*SOX (-) & $-0.056 * *$ & & & \\
\hline A_CFO*SOX (-) & & $-0.256 * * *$ & & \\
\hline A_PROD*SOX (-) & & & $-0.219 * * *$ & \\
\hline A_DISCX $*$ SOX (-) & & & & $-0.244 * * *$ \\
\hline INTERCEPT & $-0.611 * * *$ & $-0.722 * * *$ & $0.761 * * *$ & $0.728 * * *$ \\
\hline
\end{tabular}

\section{Panel B}

\begin{tabular}{|l|l|}
\hline Pre-SOX & $0.02 * *(1,250)$ \\
\hline Post-SOX & $-0.04 * *(933)$ \\
\hline Post-Pre & $-0.06 * * *$ \\
\hline
\end{tabular}

$* * *, * *$, and $*$ indicate statistical significance at the $0.01,0.05$, and 0.10 levels, respectively, using a 1 -tailed test. Tstatistics are in parentheses. Standard errors are clustered by firm. Year and industry indicator variables as well as SOX interactions with other control variables are omitted for brevity. All continuous variables are winsorized at the $1^{\text {st }}$ and $99^{\text {th }}$ percentiles. We identify suspect firm years as years in which a firms earnings scaled by assets in the current year are 0.01 more than earnings scaled by assets from the prior year. Panel A of Table 8 presents the results of estimating equations (8) and (10) for suspect firms with Fama-French three-factor abnormal returns as the dependent and DA, A_CFO, A_PROD, and $A \_D I S C X$ as the variables of interest. The columns $R E T_{t, t+3}$ represents returns for periods $t$ through $\mathrm{t}+3$. Panel $\mathrm{B}$ of Table 8 presents the cumulative abnormal return pre- and post-SOX for suspect firms. See Appendix A for detailed descriptions of all variables. 


\section{Table 10}

Tobin's $Q$ and Earnings Management

\begin{tabular}{|c|c|c|c|c|}
\hline DV & Tobin's Q & Tobin's Q & Tobin's Q & Tobin's Q \\
\hline $\mathrm{DA}$ & $-1.179 *$ & & & \\
\hline A_CFO & & $2.969 * *$ & & \\
\hline A_PROD & & & 0.583 & \\
\hline A_DISCX & & & & $1.714 * *$ \\
\hline $\mathrm{T} \overline{\mathrm{A}}$ & $6.253 *$ & 11.27 & 11.18 & 10.42 \\
\hline $\mathrm{CFO}$ & 4.121 & 5.138 & 3.913 & 3.787 \\
\hline SIZE & $0.137 * *$ & 0.149 & $0.137 * *$ & $0.229 * *$ \\
\hline IND_ROA & $0.565 * * *$ & $0.615 * * *$ & $0.667 * * *$ & $0.609 * * *$ \\
\hline RETURN & $0.012 * * *$ & $0.089 * * *$ & $0.044 * * *$ & $0.027 * * *$ \\
\hline MTB & $1.004 * * *$ & $1.003 * * *$ & $1.003 * * *$ & $1.012 * * *$ \\
\hline SG & -64.85 & -64.98 & -65.27 & -64.44 \\
\hline SOX & -0.267 & 0.533 & -0.007 & -0.116 \\
\hline $\mathrm{DA} * \mathrm{SOX}(+)$ & $2.927 * *$ & & & \\
\hline A_CFO*SOX (-) & & $-3.159 * *$ & & \\
\hline A_PROD*SOX (-) & & & $-1.291 *$ & \\
\hline A_DISCX $*$ SOX (-) & & & & $-2.919 * *$ \\
\hline INTERCEPT & $-0.292 * * *$ & $1.365 * * *$ & $0.797 * *$ & $1.262 * *$ \\
\hline
\end{tabular}

$* * *, * *$, and * indicate statistical significance at the $0.01,0.05$, and 0.10 levels, respectively, using a 1 -tailed test. Tstatistics are in parentheses. Standard errors are clustered by firm. All continuous variables are winsorized at the $1^{\text {st }}$ and $99^{\text {th }}$ percentiles. We define Tobin's $\mathrm{Q}$ as the market value of equity plus long-term debt divided by the book value of equity plus long-term debt. Table 10 presents the results of an ordinary least squares regression that uses Tobin's $\mathrm{Q}$ as the dependent variable and $D A, A_{-} C F O, A_{-} P R O D$, and $A_{-} D I S C X$ as the variables of interest. See Appendix A for detailed descriptions of the other variables. 


\section{Table 11 \\ ZSCORE and Earnings Management}

\begin{tabular}{|c|c|c|c|c|}
\hline DV & ZSCORE & ZSCORE & ZSCORE & ZSCORE \\
\hline DA & $-0.477 * * *$ & & & \\
\hline A_CFO & & $0.421 * * *$ & & \\
\hline A_PROD & & & $1.949 * * *$ & \\
\hline A_DISCX & & & & $0.456 * * *$ \\
\hline TA & $3.380 * * *$ & $1.349 * * *$ & $1.326 * * *$ & $1.799 * * *$ \\
\hline $\mathrm{CFO}$ & $2.479 * * *$ & $2.872 * * *$ & $2.506^{* * *}$ & $2.826 * * *$ \\
\hline SIZE & $0.073 * * *$ & $0.068 * * *$ & $0.033 * * *$ & $0.034 * * *$ \\
\hline IND_ROA & $0.244 * * *$ & $0.212 * * *$ & $0.261 * * *$ & $0.196 * * *$ \\
\hline RETURN & $0.122 * * *$ & $0.138 * * *$ & $0.129 * * *$ & $0.138 * * *$ \\
\hline MTB & -0.002 & -0.001 & 0.002 & $-0.005^{* *}$ \\
\hline SG & $-0.579 *$ & $-0.602 * *$ & $-0.920 * * *$ & $-0.794 * *$ \\
\hline SOX & $0.099 * * *$ & $-0.229 * * *$ & -0.164 & $-0.154 * *$ \\
\hline DA*SOX (-) & $0.390 * * *$ & & & \\
\hline A_CFO*SOX (-) & & $-0.485 * * *$ & & \\
\hline A_PROD*SOX (-) & & & $-1.519 * * *$ & \\
\hline A_DISCX ${ }^{*}$ SOX (-) & & & & $-1.045 * * *$ \\
\hline INTERCEPT & $1.775 * * *$ & $1.670 * * *$ & $1.372 * * *$ & $1.480 * * *$ \\
\hline
\end{tabular}

$* * *, * *$, and $*$ indicate statistical significance at the $0.01,0.05$, and 0.10 levels, respectively, using a 1 -tailed test. Tstatistics are in parentheses. Standard errors are clustered by firm. All continuous variables are winsorized at the $1^{\text {st }}$ and $99^{\text {th }}$ percentiles. We define ZSCORE as Altman (1968) Z-score. Table 11 presents the results of an ordinary least squares regression that uses ZSCORE as the dependent variable and $D A, A \_C F O, A \_P R O D$, and $A \_D I S C X$ as the variables of interest. See Appendix A for detailed descriptions of the other variables. 